\title{
Steel-Fibre-Reinforced Self-Compacting Concrete with 100\% Recycled Mixed Aggregates Suitable for Structural Applications
}

\author{
* Corresponding author: \\ $\mathrm{PhD}$ Civil Engineer \\ Department of Civil and Environmental Engineering \\ Universitat Politécnica de Cataluña

Keywords: A. Fibres; A. Recycling; B. Mechanical properties; B. Residual/internal stress; Self-compacting

\begin{abstract}
This research focuses on designing and characterizing steel-fibre-reinforced self-compacting concrete using recycled aggregates (SFR-SCC-RA).Six different concrete dosages have been designed, and two extensive mechanical and physical characterization programs have been conducted. The first program was developed in a concrete production plant to verify the compatibility of the new material with the existing production systems. The second program was developed in a laboratory under controlled temperature and humidity conditions. Although compressive strengths greater than 25 $\mathrm{N} / \mathrm{mm}^{2}$ have been reached (which allows the material to be classified as structural), the design in this initial phase is oriented to applications with limited mechanical requirements (e.g., foundations, earth retaining walls and pavements, in which design forces are moderate).
\end{abstract}




\section{INTRODUCTION}

The social perception in reference to the construction sector and, in particular, the use of concrete as a building material has become increasingly negative [1]. Cement production is one of the most energy intensive processes: the cement industry consumes $5 \%$ of the total global industrial energy. Due to the dominant use of carbon intensive fuels, e.g., coal, in clinker making, cement manufacture is a major emitter of $\mathrm{CO}_{2}$. More than $5 \%$ of the total global emissions of $\mathrm{CO}_{2}$ are attributed to the cement sector; it contributes the same proportion of emissions to greenhouse gas emission [2,3].

One way to promote more sustainable construction and minimize its impact on the environment is to apply the following "3Rs" concept: reduce - reuse - recycle [4]. Strategies have already been adopted to reduce the amount of $\mathrm{CO}_{2}$ emitted into the atmosphere through measures such as reducing the percentage of clinker in cement by partially replacing additives such as fly ash, blast furnace slag, silica fume or pozzolan, among others, and replacing concrete aggregates with recycled aggregates [5-11].

The sources of aggregates for the construction industry in Europe are shown in Figure $1[12]$. More than $90 \%$ consists of natural aggregates extracted from quarries and gravel pits, which contributes to the negative ecological impact and the negative social view of the material. In contrast, only $5 \%$ of global production involves recycled aggregates (RA, hereinafter) from construction waste and demolition. This percentage of reuse is low because of technological challenges (formulation and manufacturing, mechanical problems and durability) associated with the use of RA in structural concrete and also the particular constraints associated with the regulations in each country. Although the literature concerning the technological aspects of using RA is extensive, the construction sector is still not predisposed to use this material in structural applications.

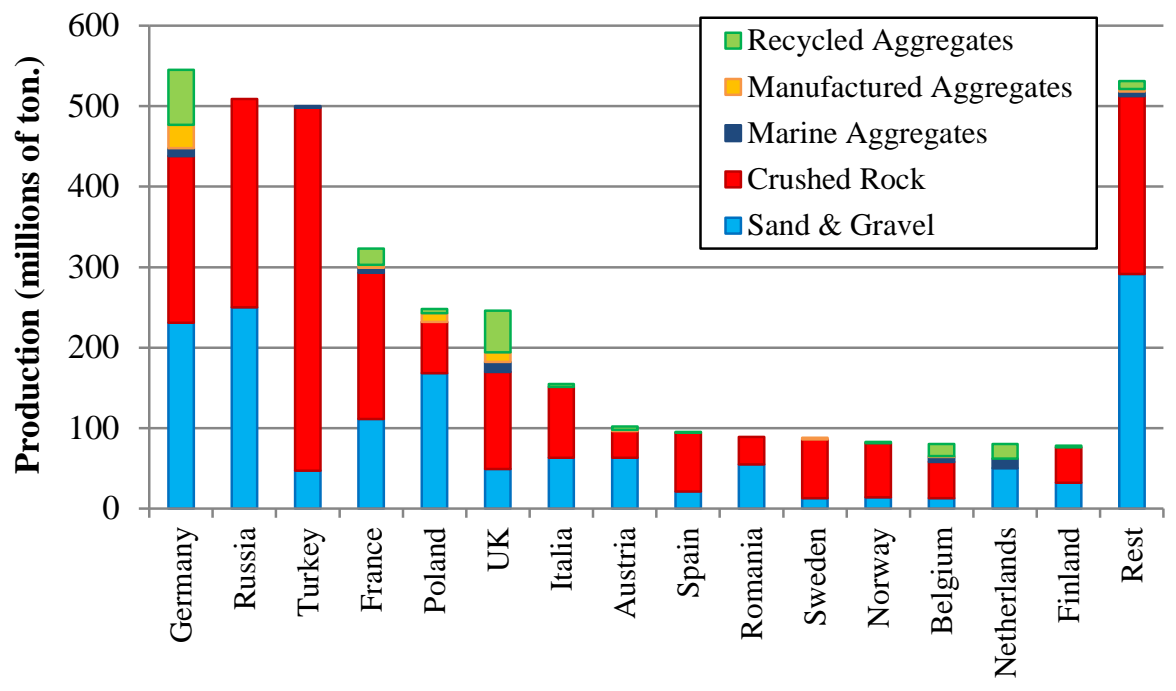

Figure 1. Production of aggregate by country and proportion according to its origin [12]

The main benefits that are achieved with the reuse of construction and demolition waste, as [13] note, include the following: (1) the conservation of natural resources; (2) a reduction in the energy consumption associated with the production and transport of aggregates; and (3) a solution to the current problem of uncontrolled dumping of waste. 
However, the use of RA is limited by the recommendations established by various national regulations; in particular, mixed RA only used in non-structural applications [14-17]. The reason is that the compressive and tensile strength of concrete, as well as the modulus of elasticity, are affected by the use of RA, which directly affects the overall performance of the structure [18].

According to [19], the losses in strength when using RA are due to (1) the lower mechanical strength of the RA, (2) the greater water absorption of the RA and (3) an increase in fragile areas within the concrete (e.g., the interfacial transition zone). [20] found that the interfacial transition zone had a high porosity.[21] found that concrete with RA from concrete requires a greater cement content to reach the compressive strength of conventional concrete. [22] recorded a loss of $20 \%$ to $25 \%$ of the compressive strength of concrete at $28 \mathrm{~d}$ for full replacement of coarse RA; when $25 \%$ of the aggregates were replaced, there were no significant changes to the compressive strength.

The quality of recycled concrete aggregates (RCA) is usually lower than the quality of natural aggregates [23]. In comparison with natural normal-weight aggregates, RCA are weaker, more porous and exhibit higher values of water absorption [24]. The density of concrete constructed from RCA is as much as $10 \%$ lower than concrete constructed from natural aggregates $[19,20]$.

The water absorption of RCA ranges from 3.5\% to 9.2\% [24-27], which greatly affects the workability of the fresh concrete. Previous studies [28,29] have demonstrated that, in contrast to natural aggregates, in which absorption is relatively fast, absorption in RA is prolonged by as much as $24 \mathrm{hr}$ or longer, potentially lasting as long as 96 to $120 \mathrm{hr}$. However, if proper presaturation of the aggregates is performed, satisfactory results can be obtained in terms of workability and mechanical behavior [30]. In addition, the granulometry of the RA also has a large influence because at the same density, the water absorption of fine aggregate can be up to $5 \%$ greater than that of coarse aggregate, which has a smaller surface area [31].

Generally, the use of construction and demolition waste for the manufacture of structural concrete is only partial, which precludes full revalorization of the product obtained. As such, there is room for improvement. In Spain, for example, the use of recycled aggregates in concrete for structural purposes is limited in the Spanish standard EHE-08 [32] to a maximum percentage of $20 \%$ substitution of the coarse fraction if the aggregates have been obtained from the crushing of concrete and their water absorption is less than 7\%. EHE-08 requires that when exceeding $20 \%$ substitution, the suitability must be certified based on specific studies and further experimentation; this requirement leaves open the possibility of using high contents of recycled aggregate in structural applications of concrete. This approach is identical to that established in the UK and the Netherlands.

In contrast, other European countries are more flexible in allowing higher percentages of substitution. For example, in Germany, the percentage of substitution is between 25 and $45 \%$, depending on the type of aggregate and the environment to which the concrete will be exposed, while up to $100 \%$ is allowed in Belgium and Denmark. The latter two countries even allow a restricted use of recycled fine aggregates.

This research focuses on designing and characterizing steel-fibre-reinforced selfcompacting concrete using recycled aggregates (SFR-SCC-RA). To our knowledge, this material has not previously been reported in the literature. 
The use of fibres to reinforce concrete is a standard practice and is regulated by the fib Model Code 2010 [33]. The main advantages are the optimization of execution times due to the partial or total elimination of the prestressed reinforcement and the increased post-cracking energy of the concrete, leading to more suitable cracking patterns to ensure the life of the structure [34,35]. Typical applications of fibre-reinforced concrete (FRC) are, for example, rings for lining tunnels [36,38] and sewerage pipelines [39,40]; it has been shown that the substitution of part or all of traditional passive reinforcement fibres in such applications also leads to clear and quantifiable advantages in terms of sustainability [41]. Moreover, the selfcompactability of concrete reduces noise pollution and risks associated with the handling of vibrators [42], in addition to increasing the production rate and minimizing the probability of occurrence of voids and other finishing problems that can cause aesthetic defects or even compromise the durability of the structure. Ultimately, all of these added features improve the sustainability of the finished product.

Based on these factors, the purpose of this paper is to validate the potential of SFR-SCC-RA as a new cement base material whose components and joint response validate its use as a sustainable alternative. The target structures for this material, in the development phase, are those with limited structural requirements (pavements, foundations and walls with reduced design loads). Thus, an extensive experimental program was conducted to produce this material, mechanically and physically characterize it and analyze the results.

\section{EXPERIMENTAL PROGRAM}

Two experimental stages were conducted, in which twelve batches of SFR-SCC-RA were produced and several relevant formulation parameters were varied. The first stage (six batches) was performed in the facilities of a concrete producer to reproduce the actual conditions of a manufacturing environment and to verify its adaptability to existing systems and methods. The second stage (six remaining batches) was performed at the "Luis Agulló" Laboratory of Structural Technology (Laboratorio de Tecnología de Estructuras LTE) of the Polytechnic University of Catalonia to complement and extend the results obtained in the previous stage in an environment with more controlled boundary conditions.

\subsection{SRF-SCC-RA mix proportions and materials}

The cement used was CEM II/A-M (V-L) $42.5 \mathrm{R}$, with a density of $3.06 \mathrm{~g} / \mathrm{cm}^{3}$ and a Blaine surface of $4930 \mathrm{~cm}^{2} / \mathrm{g}$, with additives (fly ash and limestone filler). The natural aggregates were limestones of $0 / 4 \mathrm{~mm}$ and $6 / 12 \mathrm{~mm}$ particle size, referred to as $0 / 4-\mathrm{T}$-L and $6 / 12-\mathrm{T}$-L, respectively. In addition, two types of RA, one with a $4 / 12 \mathrm{~mm}(4 / 12-\mathrm{T}-\mathrm{R})$ particle size and the other with a 12/20 mm (12/20-T-R) particle size, were used. The Recycled aggregates were composed mainly of mortar, clean aggregate, ceramics and other minor components such as glass, plaster, wood and even organic matter. ' $\mathrm{T}$ ' indicates that the process of obtaining the aggregate was by trituration; 'L' denotes limestone, and ' $R$ ' denotes recycled.

The granulometric curves of the four types of aggregates, obtained according to the standards [43.44], are shown in Figure 2. The composition of the two types of recycled aggregate was analyzed according the methodology given in standard [45]; the results are presented in Table 1. In the same table, values of the real ( $\left.\boldsymbol{\rho}_{\text {real }}\right)$ and apparent ( $\left.\boldsymbol{\rho}_{\text {ap }}\right)$ densities are included as well as the absorption of water after $24 \mathrm{hrs}$ estimated with standards $[46,47]$, respectively, for each particle size. 
177

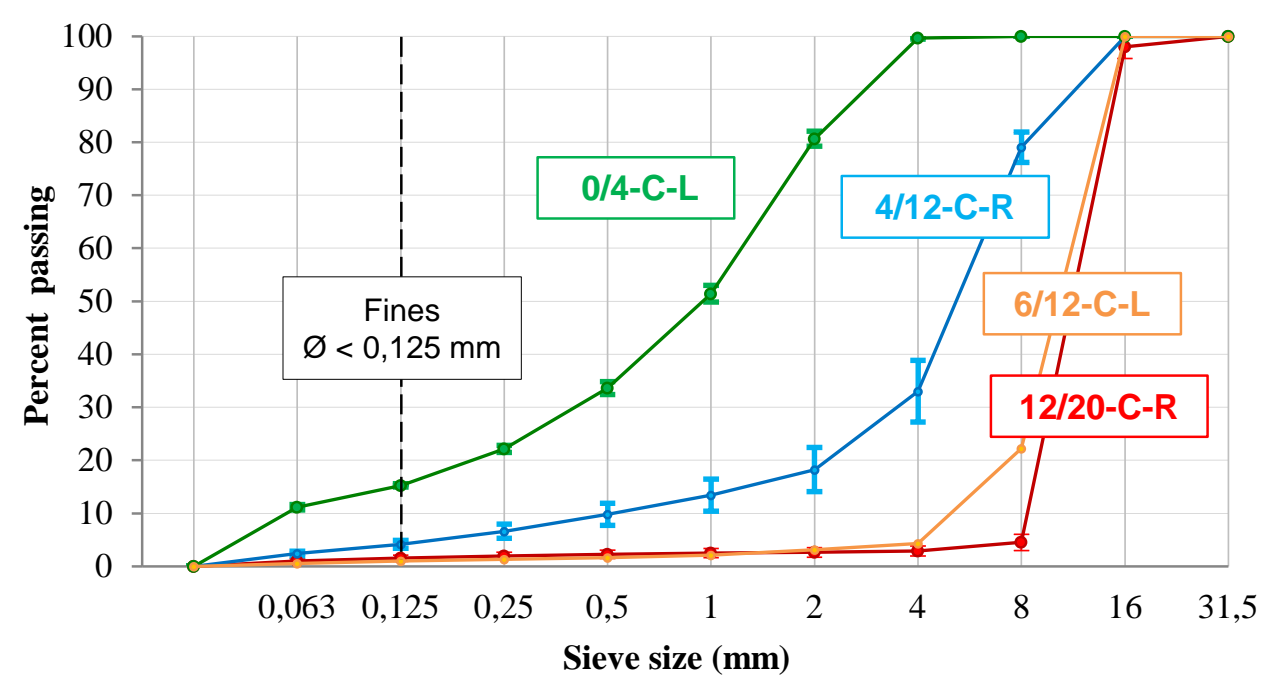

Figure 2. Granulometric curves of the aggregates

\begin{tabular}{|c|c|c|c|c|c|c|c|c|}
\hline Aggregates & \multicolumn{4}{|c|}{ Composition (\%) } & \multicolumn{3}{c|}{ Physical properties } \\
\hline Granulometry & $\begin{array}{c}\text { Aggregates } \\
\text { without } \\
\text { mortar }\end{array}$ & $\begin{array}{c}\text { Aggregates } \\
\text { with } \\
\text { mortar }\end{array}$ & Ceramic & Glass & Others & $\begin{array}{c}\boldsymbol{\rho}_{\text {ap }} \\
\left(\mathbf{g} / \mathbf{c m}^{3}\right)\end{array}$ & $\begin{array}{c}\boldsymbol{\rho}_{\text {real }} \\
\left(\mathbf{g} / \mathbf{c m}^{3} \text { ) }\right.\end{array}$ & $\begin{array}{c}\text { Absorption } \\
\mathbf{2 4} \mathbf{~ h}(\%)\end{array}$ \\
\hline 4/12-C-R & 59.87 & 31.47 & 6.66 & 0.05 & 1.95 & 2.67 & 2.06 & 11.06 \\
\hline $12 / 20-\mathrm{C}-\mathrm{R}$ & 46.47 & 34.09 & 15.47 & 0.26 & 3.71 & 2.61 & 2.19 & 7.30 \\
\hline
\end{tabular}

Table 1. Composition and physical properties of the $R A$

Two types of hooked-end steel fibres, presented in Table 2, were characterized by strength $\left(\mathbf{f}_{\mathbf{f}}\right)$, length $\left(\mathbf{l}_{\mathbf{f}}\right)$, diameter $\left(\boldsymbol{\Phi}_{\mathbf{f}}\right)$ and certain other properties, in order to analyze the influence of fibre type on the behavior of the fresh material (workability and self-compactability) and that in the hardened state (post-cracking strength of the concrete),

\begin{tabular}{|c|c|c|c|c|c|}
\hline Fibre type & $\mathbf{f}_{\mathbf{f}}\left(\mathbf{N} / \mathbf{m m}^{\mathbf{2}}\right)$ & $\mathbf{l}_{\mathbf{f}}(\mathbf{m m})$ & $\emptyset_{\mathbf{f}}(\mathbf{m m})$ & $\boldsymbol{\lambda}\left(\mathbf{l}_{\mathbf{f}} / \emptyset_{\mathbf{f}}\right)$ & Fibres $/ \mathbf{k g}$ \\
\hline M502 & $1000 \pm 150$ & $50 \pm 5$ & $1.00 \pm 0.10$ & 50 & 3000 \\
\hline M503 & $1200 \pm 180$ & $35 \pm 4$ & $0.75 \pm 0.08$ & 46 & 8000 \\
\hline
\end{tabular}

Table 2. Properties of the fibres

A composition of $20 \mathrm{~kg} / \mathrm{m}^{3}$ was used to guarantee a minimum ductility of the material as well as a sufficient post-cracking strength to prevent any brittle fractures $[48,49]$. This minimum amount is suggested in the EHE-08 for structural elements with low mechanical responsibility.

The following chemical additives were used: a plasticizer (lignosulfonate), a superplasticizer (polycarboxylate) and an experimental additive that prevents water absorption in RA. This additive generates a hydrophobic film around the recycled aggregates, thereby minimizing water absorption by the fraction of RA, as an alternative to pre-saturation with water to avoid an increase of the porosity in the concrete containing 100\% RA and a resulting decrease in mechanical strength and durability. 
Table 3 shows the SFR-SCC-RA dosages that were produced for both stages. Some slight variations were carried out during the $2^{\text {nd }}$ experimental phase (laboratory) to adapt the dosages to the particular conditions. The nomenclature used for the classifications of the concretes is $\mathrm{T} / \mathrm{C}$ MSA- $\mathbf{l}_{\mathbf{f}}+\mathrm{I}$, where $\mathrm{T}$ is the type of concrete (NA: natural coarse aggregate, RA: recycled coarse aggregate, FRC-RA: reinforced with fibres and recycled coarse aggregate); $\mathrm{C}$ is consistency, self-compacting (SC) in all cases; MSA is the maximum aggregate size; $\mathbf{l}_{\mathbf{f}}$ is the maximum fibre length in $\mathrm{mm}$ (if it contains fibre); and I denotes the presence of an absorption inhibitor additive.

\begin{tabular}{|c|c|c|c|c|c|c|}
\hline Material & NA/SC 12 & RA/SC 12 & RA/SC 20 & $\begin{array}{c}\text { RA/SC } \\
20+I\end{array}$ & $\begin{array}{c}\text { FRC-RA/SC } \\
12-35 \\
\end{array}$ & $\begin{array}{c}\text { FRC-RA/SC } \\
20-50 \\
\end{array}$ \\
\hline Cement & 355 & 370 & 370 & 370 & 370 & 370 \\
\hline 0/4-C-L & 1230 & 1200 & 1210 & 1210 & 1260 & 1260 \\
\hline 6/12-C-L & 580 & -- & -- & -- & -- & -- \\
\hline $\begin{array}{c}\text { 4/12-C-R } \\
\text { Aggr. without mortar } \\
\text { Aggr. with mortar } \\
\text { Ceramic } \\
\text { Saturation water } \\
\text { Others }\end{array}$ & -- & $\begin{array}{c}590 \\
318(353) \\
167(186) \\
35(39) \\
59 \\
11(12) \\
\end{array}$ & $\begin{array}{c}180 \\
97(108) \\
51(57) \\
11(12) \\
18 \\
3(4)\end{array}$ & $\begin{array}{c}200 \\
108(120) \\
57(63) \\
12(13) \\
20 \\
3(4)\end{array}$ & $\begin{array}{c}520 \\
280(311) \\
147(164) \\
31(35) \\
52 \\
9(10) \\
\end{array}$ & $\begin{array}{c}180 \\
97(108) \\
51(57) \\
11(12) \\
18 \\
3(4)\end{array}$ \\
\hline $\begin{array}{c}\text { 12/20-C-R } \\
\text { Aggr. without mortar } \\
\text { Aggr. with mortar } \\
\text { Ceramic } \\
\text { Saturation water } \\
\text { Others } \\
\end{array}$ & -- & -- & $\begin{array}{c}360 \\
151(167) \\
111(123) \\
50(56) \\
36 \\
12(14) \\
\end{array}$ & $\begin{array}{c}390 \\
168(181) \\
123(133) \\
56(60) \\
39 \\
13(15) \\
\end{array}$ & -- & $\begin{array}{c}340 \\
142(158) \\
104(116) \\
47(53) \\
34 \\
11(14) \\
\end{array}$ \\
\hline M502 fibres & -- & -- & -- & -- & -- & 20 \\
\hline M503 fibres & -- & -- & -- & -- & 20 & -- \\
\hline Water & 170 & $165(160)$ & 150 & $170(185)$ & 175 & 160 \\
\hline Saturation water & -- & $(31.7)$ & $(18.2)$ & -- & $(27.9)$ & $(17.7)$ \\
\hline Inhibitor & -- & -- & -- & 1.5 & -- & -- \\
\hline Lignosulphonate & 2.2 & 2.6 & $2.2(2.6)$ & 2.6 & 2.6 & 2.6 \\
\hline Polycarboxylate & $6.8(7.3)$ & $6.8(7.3)$ & 6.8 & $6.8(9.7)$ & 7.3 & 7.3 \\
\hline Total & 2344 & $\begin{array}{c}2334 \\
(2329) \\
\end{array}$ & 2279 & $\begin{array}{c}2351 \\
(2331) \\
\end{array}$ & $\begin{array}{c}2355 \\
(2340) \\
\end{array}$ & 2340 \\
\hline Fines & 548.4 & 577.5 & 567.4 & 568.7 & 583.7 & 574.5 \\
\hline Effective w/c & 0.479 & $\begin{array}{c}0.446 \\
(0.432) \\
\end{array}$ & 0.405 & $\begin{array}{c}0.459 \\
(0.500) \\
\end{array}$ & 0.473 & $\begin{array}{c}0.432 \\
(0.446) \\
\end{array}$ \\
\hline Volume stage $1\left(\mathrm{~m}^{3}\right)$ & 3.0 & 3.0 & 6.0 & 6.0 & 6.0 & 6.0 \\
\hline Volume stage 2 (l) & 30 & 30 & 30 & 30 & 20 & 20 \\
\hline
\end{tabular}

Table 3. Contents $\left(\mathrm{kg} / \mathrm{m}^{3}\right)$ for the different concrete dosages. In parenthesis those values that have been 
The formulations corresponding to the second experimental stage, conducted in the laboratory are not exactly the same as those of the first stage, as slight variations were introduced to improve the manufacturing process by adapting to the laboratory conditions.

\subsection{Mixing method and fresh state characterization}

\subsubsection{First stage (mixing plant)}

The manufacturing process started (except in the reference formulation NA/SC 12) with pre-saturation of the recycled aggregates using the two following procedures: water saturation (RA and FRC-RA formulations) and treatment with absorption-inhibitor additive (RA/SC-20+I formulation).

Subsequently, in the case of FRC, the steel fibres were added; if any deficiency was observed after mixing, it was corrected by increasing the mixing time or modifying the dosage. Conversely, if the appearance of the mixture was appropriate, the slump flow assay was performed according to standard [50] to verify the self-compactability of the concrete.

If the result of this test was a diameter less than $55 \mathrm{~cm}$, more water was added, and the additional volume was recorded. Then, it was mixed at high intensity for an additional 2 min, and the test was repeated. If the trial again gave an insufficient result, more water or superplasticizer was added. Finally, the specimens were molded for physical and mechanical characterization.

\subsubsection{Second stage (laboratory)}

One of the main changes in the second experimental stage in the laboratory is the manufacturing process, specifically the explicit differentiation between free water (for hydrating cement particles) and the water saturation of RA.

The pre-saturation of RA was performed based on their physical properties, such as their moisture content, absorption and an adjustment factor based on the ratio of water absorbed after 10 min and after 24 hrs., which is approximately 0.8 [29,51].

Each batch consisted of a volume of $30 \mathrm{l}$ (the maximum capacity of the 65-2 K3 COLLOMATIC mixer). The mixing method used was that recommended by [52], as follows: (1) mix the RA and water saturation for $1 \mathrm{~min}$ at high intensity; (2) mix the saturated RA with natural 0/4-T-C sand for another minute; (3) add the cement to the aggregates and dry mix for an additional $30 \mathrm{~s}$; (4) after this interval, add two-thirds of the total free water and the mixture of aggregate, cement and water; mix the combination for another minute; (5) add the two additives, followed by the plasticizer, the superplasticizer, the steel fibres and the last one-third of the free water; and, finally, (6) mix at high intensity for $90 \mathrm{s.}$

To verify that the manufactured concrete complied with the conditions of selfcompactability, a slump flow test was performed immediately after the mixing process. If the minimum diameter of $55 \mathrm{~cm}$ was reached, the corresponding test specimens were filled with the concrete remaining in the mixer.

Once 24 hrs had passed after fabrication, the specimens were unmolded and stored in a humid chamber in the laboratory at constant relative humidity (>95\%) and temperature $\left(20^{\circ} \mathrm{C}\right)$ until they were tested. In total, 347 specimens were manufactured and tested. 


\subsection{Characterization of SRF-SCC-RA in hardened state}

Table 4 details the physical and mechanical characterization tests carried out on the hardened concrete.

\begin{tabular}{|c|c|c|c|c|c|}
\hline Properties & Standard & Stage & Dosages & Specimen & Age \\
\hline \multirow{2}{*}{$\begin{array}{l}\text { Porosity } \\
\text { Density }\end{array}$} & \multirow{2}{*}{ [58] } & \multirow{2}{*}{$1^{\text {st }}$} & \multirow{2}{*}{ All } & \multirow{2}{*}{$\begin{array}{c}\text { Cubic } \\
150 \times 150 \times 150\end{array}$} & $180 \mathrm{~d}$ \\
\hline & & & & & $365 \mathrm{~d}$ \\
\hline \multirow{2}{*}{$\begin{array}{c}\text { Fibre } \\
\text { orientation }\end{array}$} & \multirow{2}{*}{$\begin{array}{c}\text { Inductive } \\
\text { method } \\
{[53]}\end{array}$} & $1^{\text {st }}$ & $\begin{array}{l}\text { FRC-RA/SC 12-35 } \\
\text { FRC-RA/SC 20-50 } \\
\end{array}$ & $\begin{array}{c}\text { Cubic } \\
\text { 150x150x150 }\end{array}$ & - \\
\hline & & $2^{\text {nd }}$ & $\begin{array}{l}\text { FRC-RA/SC 12-35 } \\
\text { FRC-RA/SC 20-50 }\end{array}$ & $\begin{array}{c}\text { Cubic } \\
150 \times 150 \times 150\end{array}$ & - \\
\hline \multirow{5}{*}{$\begin{array}{l}\text { Compressive } \\
\text { strength }\end{array}$} & \multirow{5}{*}{ [59] } & \multirow{3}{*}{$1^{\text {st }}$} & \multirow{3}{*}{ All } & \multirow{3}{*}{$\begin{array}{c}\text { Cylindrical } \\
150 \times 300\end{array}$} & $7 \mathrm{~d}$ \\
\hline & & & & & $28 \mathrm{~d}$ \\
\hline & & & & & $\frac{90 \mathrm{~d}}{365 \mathrm{~d}}$ \\
\hline & & \multirow[b]{2}{*}{$2^{\text {nd }}$} & \multirow[b]{2}{*}{ All } & \multirow[b]{2}{*}{$\begin{array}{l}\text { Cylindrical } \\
100 \times 200\end{array}$} & $7 \mathrm{~d}$ \\
\hline & & & & & $\frac{28 \mathrm{~d}}{365 \mathrm{~d}}$ \\
\hline $\begin{array}{l}\text { Flexural } \\
\text { strength }\end{array}$ & {$[60]$} & $1^{\text {st }}$ & RA and FRC-RA & $\begin{array}{c}\text { Prismatic } \\
100 \times 100 \times 400\end{array}$ & $28 \mathrm{~d}$ \\
\hline \multirow{2}{*}{$\begin{array}{l}\text { Young's } \\
\text { modulus }\end{array}$} & \multirow{2}{*}{ [61] } & \multirow{2}{*}{$2^{\text {nd }}$} & \multirow{2}{*}{ All } & \multirow{2}{*}{$\begin{array}{l}\text { Cylindrical } \\
\text { 100x200 }\end{array}$} & $28 \mathrm{~d}$ \\
\hline & & & & & $365 \mathrm{~d}$ \\
\hline \multirow{2}{*}{$\begin{array}{l}\text { Post-cracking } \\
\text { residual } \\
\text { strength and } \\
\text { toughness }\end{array}$} & [55] & $2^{\text {nd }}$ & $\begin{array}{l}\text { FRC-RA/SC 12-35 } \\
\text { FRC-RA/SC 20-50 }\end{array}$ & $\begin{array}{c}\text { Cylindrical } \\
150 \times 150\end{array}$ & $28 \mathrm{~d}$ \\
\hline & $\begin{array}{c}\text { Multidirectional } \\
{[57]}\end{array}$ & $2^{\text {nd }}$ & $\begin{array}{l}\text { FRC-RA/SC 12-35 } \\
\text { FRC-RA/SC 20-50 }\end{array}$ & $\begin{array}{c}\text { Cubic } \\
150 \times 150 \times 150\end{array}$ & $28 \mathrm{~d}$ \\
\hline
\end{tabular}

Table 4. Tests for characterization of the physical and mechanical properties

The amount $\left(\mathbf{C}_{\mathbf{f}}\right)$ and orientation of the steel fibres was characterized in cubic samples by nondestructive magnetic induction as described elsewhere [53]. The method is based on measuring the increase in inductance generated by the fibres contained in the specimen. The increase depends on the type of steel and on $\mathbf{C}_{\mathbf{f}}$. The steel fibres have ferromagnetic properties and modify the properties pf the uniform magnetic field induced by a discontinuous coil mounted on a plastic cell (Figure 3). An HP-4192 impedance analyzer with an error reading below $5 \%$ was used.
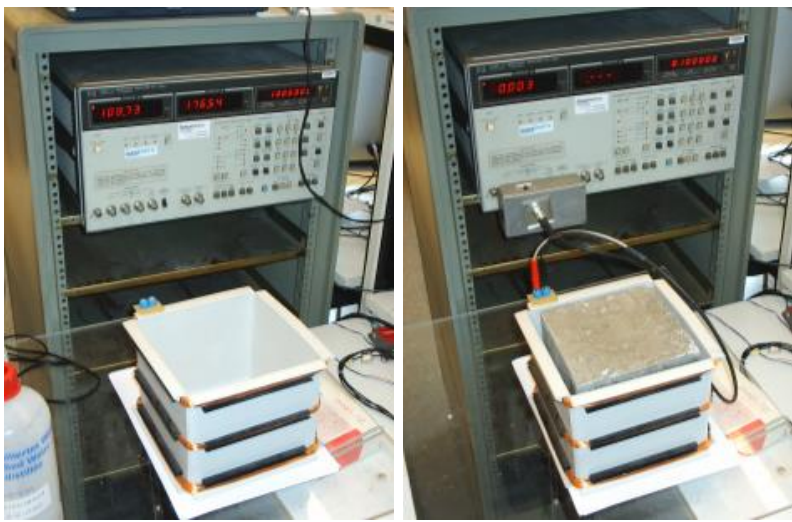

Figure 3. Device for estimating the number of fibres via a magnetic induction test 
The mechanical characterization tests, such as the compressive strength $\left(\mathbf{f}_{\mathbf{c}}\right)$, flexural tension $\left(\mathbf{f}_{\mathbf{c t}, \mathbf{f}}\right)$, toughness $\left(\mathbf{G}_{\mathbf{f}}\right)$ and elastic modulus $\left(\mathbf{E}_{\mathbf{c}}\right)$, were carried out using an Ibertest press with a 3 MN load capacity and displacement control.

The pre/post-cracking behavior and the toughness $\mathbf{G}_{\mathbf{f}}$ were determined via the Barcelona test $(B C N)$ in its original version $[54,55]$, with strain gauge chain installed on the cylindrical test specimens (see Figure 4a). Complementarily, the BCN test adapted to a cubic test specimen was performed $[56,57]$ to assess the post-cracking response of the material by only recording the vertical displacement of the piston and the total number of cracks produced (see Figure $4 \mathrm{~b}$ ).
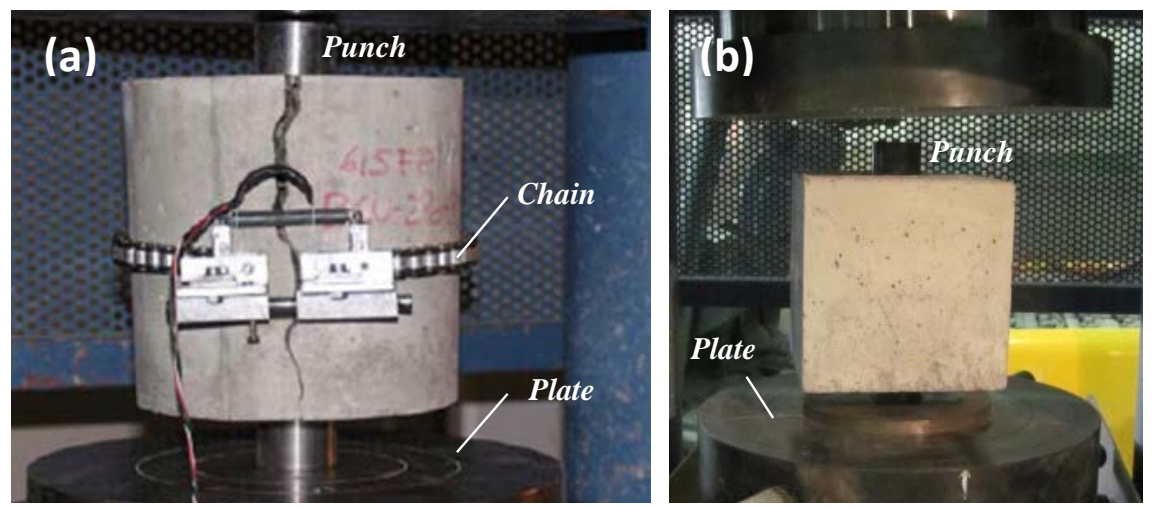

Figure 4. BCN test (a) on the cylindrical test specimen and with a strain gauge chain and (b) on the cubic test specimen and with control of the vertical displacement of the piston (without chain)

\section{RESULTS AND DISCUSSION}

\subsection{Concrete in the fresh state: slump flow}

Figure 5 shows the diameter of the slump flow extension (e) obtained in all concrete dosages from both experimental stages. The minimum criterion of self-compactability $(\mathbf{e} \geq 55$ $\mathrm{cm}$ ) is achieved in all formulations except the RA/SC 20+I and FRC-RA/SC 20-50 dosages, both in the laboratory and with $\mathbf{e}=48 \mathrm{~cm}$; in the plant, all the concretes meet this criterion of selfcompactability. These results confirm that it is possible to achieve consistencies suitable for fulfilling the self-compactability criterion by substituting the natural aggregate with mixed RA if the RA is pre-saturated.

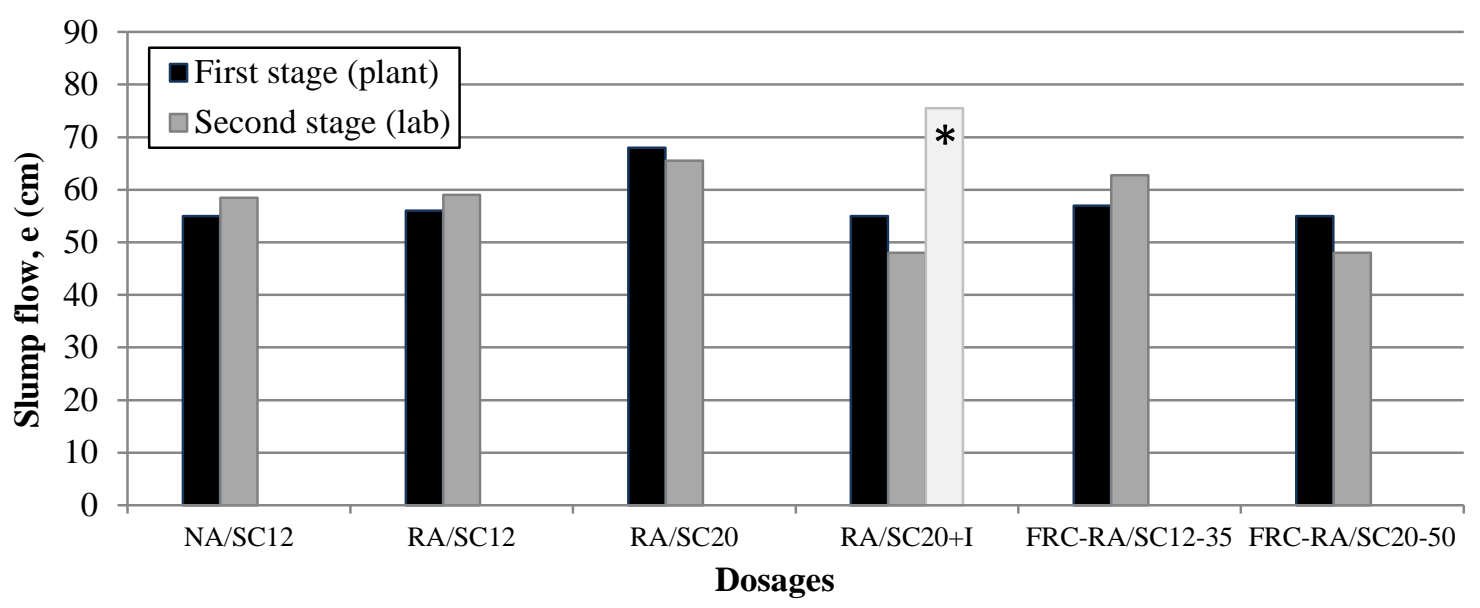

Figure 5. Slump flow obtained in the different dosages 
For the RA/SC $20+\mathrm{I}\left(^{*}\right)$ dosage, the superplasticizer content was increased from $7.3 \mathrm{l} / \mathrm{m}^{3}$ to $9.7 \mathrm{l} / \mathrm{m}^{3}$ (2.5\% s.p.c.) with the goal of reaching the self-compactability criterion. The reduced effectiveness of the experimental water-repellent additive can be attributed to two reasons: (1) the high absorption of the RA may favor the aggregates absorbing part of the additive and (2) a percentage of the additive adheres to the inner walls of the vat, thus reducing the effective amount of additive.

In addition, in light of the values of $\mathbf{e}$ obtained for the RA/SC 12 (without fibres, $\mathbf{e}_{\min }=55$ $\mathrm{cm}$ ) and FRC-RA/SC 12-35 (with fibres, $\mathbf{e}_{\min }=57 \mathrm{~cm}$ ) dosage, the viability of reaching selfcompacting consistencies is confirmed in the FRC dosages. With the increase of $\mathbf{l}_{\mathbf{f}}$ from $35 \mathrm{~mm}$ (FRC-RA/SC 12-35) to $50 \mathrm{~mm}$ (FRC-RA/SC 20-50), the value of e decreases by $3.5 \%$ and $22.0 \%$ for the dosages in the plant and in the laboratory, respectively. It is known that the reduction in the aspect ratio of the fibre $\left(\boldsymbol{\lambda}_{\mathbf{f}}\right)$ hinders movement of the mass of concrete in the fresh state both for steel fibres [62] and plastic fibres [63]. Thus, it is necessary to emphasize that the M502 fibres $\left(\mathbf{l}_{\mathbf{f}}=50 \mathrm{~mm}\right.$ and $\left.\lambda_{\mathbf{f}}=50\right)$ have an aspect ratio $8.7 \%$ greater than the M503 fibres $\left(\mathbf{l}_{\mathbf{f}}=35\right.$ $\mathrm{mm}$ and $\left.\boldsymbol{\lambda}_{\mathrm{f}}=46\right)$.

For the same maximum aggregate size, the obtained slump flow is in theory independent of the type of aggregate used (natural or recycled). Nevertheless, by comparing the two dosages of FRC, it is verified that the increase in the maximum RA size of $12 \mathrm{~mm}$ (RA/SC 12, $\mathbf{e}_{\mathbf{m i n}}=56$ $\mathrm{cm})$ to $20 \mathrm{~mm}\left(\mathrm{RA} / \mathrm{SC} 20, \mathbf{e}_{\min }=66 \mathrm{~cm}\right.$ ) does not translate to a loss of workability. This finding could contradict previous recommendations on the limitation of maximum aggregate size for self-compacting concretes $[64,65]$.

In general, the results obtained are consistent with the observations of [66]. These authors obtained slump flows similar to or even greater than conventional concrete by replacing the coarse and fine fractions with RA from crushed concrete. It should be noted that the aggregates were introduced in the saturated dry-surface state.

\subsection{Concrete in the hardened state}

\subsubsection{Physical properties}

\section{Apparent density and porosity}

Figure 6 shows the experimental results obtained from the tests of apparent density ( $\boldsymbol{\rho}_{\mathrm{ap}}$ ) and porosity $(\boldsymbol{\eta})$ on test specimens molded in the plant. The test specimens were kept in a climate chamber under controlled temperature $\left(20^{\circ} \mathrm{C} \pm 2^{\circ} \mathrm{C}\right)$ and relative humidity $(50 \% \pm 5 \%)$ conditions.

The value of $\boldsymbol{\rho}_{\text {ap }}$ in all cases (including the reference formulation) is situated in the interval from 2.0 to $2.3 \mathrm{~g} / \mathrm{cm}^{3}$, which are values lower than that of conventional vibrated concrete. This reduction corresponds to the greater content of fine aggregates required for self-compacting concrete (i.e., a greater content of paste) and to the lower density of the RA; for this reason, the three dosages that contain mixed RA exhibit, on average, a value of $\rho_{\text {ap }} 6.5 \%$ less than the reference concrete NA/SC 12 . These results are consistent with typical values in the technical literature for concrete with mixed RA [67], and these are slightly lower than the case of RA from concrete $[22,68-70]$. 
361

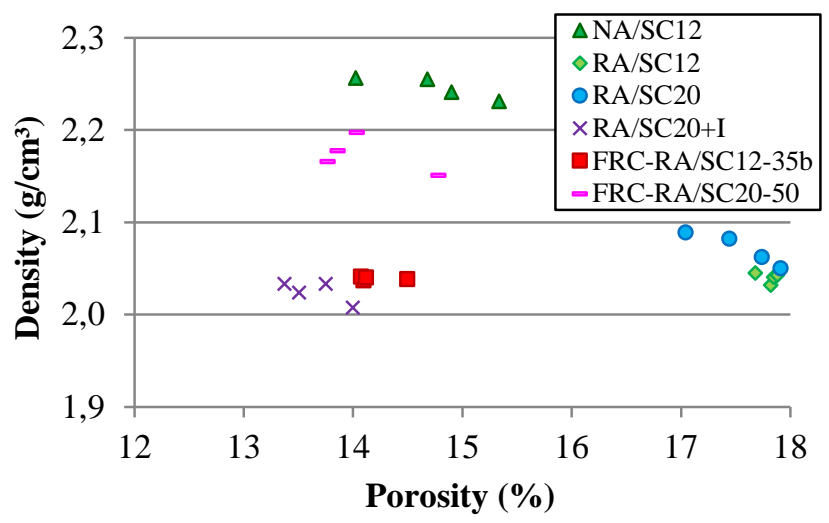

Figure 6. Relation apparent density $\left(\rho_{a p}\right)-$ porosity $(\eta)$

The second highlighted aspect is the difference in $\boldsymbol{\eta}$ depending on the saturation system. For the same type of aggregate, the average value of $\boldsymbol{\eta}\left(\boldsymbol{\eta}_{\mathrm{av}}\right)$ for formulations with watersaturated aggregates (RA/SC 12 and RA/SC $20, \eta_{\mathrm{av}}=17.8 \%$ and $17.5 \%$, respectively) is on average $29.2 \%$ higher than that obtained in the RA/SC $20+\mathrm{I}$ formulation $\left(\boldsymbol{\eta}_{\mathrm{av}}=13.7 \%\right)$, in which the water-repellent additive was used, and $20.4 \%$ higher than the reference formulation NA/SC $12\left(\eta_{\mathrm{av}}=14.7 \%\right)$, in which no saturation treatment was performed. This trend seems to contradict the hypothesis of excessive water saturation in the RA concrete dosages. Under this hypothesis, when excess water located around the RA evaporates, additional concentrated porosity is generated, especially at the interface between the RA and the paste.

Based on these results, it is concluded that the differences in $\boldsymbol{\eta}$ and $\boldsymbol{\rho}_{\mathbf{a p}}$ observed between the RA and FRC concrete dosages are not due to the use of steel fibres but to differences in the content of RA and the manufacturing process.

\section{Fibre orientation}

This section compares the results obtained by applying the inductive method [53] on test specimens molded both in the concrete plant and in the laboratory. The criterion for identifying the orientation direction of the fibres in the cubic test specimen is the vertical axis (1) and the horizontal plane (orthogonal axes 2 and 3). Figure 7 indicates the proportion of fibres oriented along each axis. A total of 18 samples with formulations FRC/SC 12-35 (10) and FRC/SC 20-50 (8) were tested.

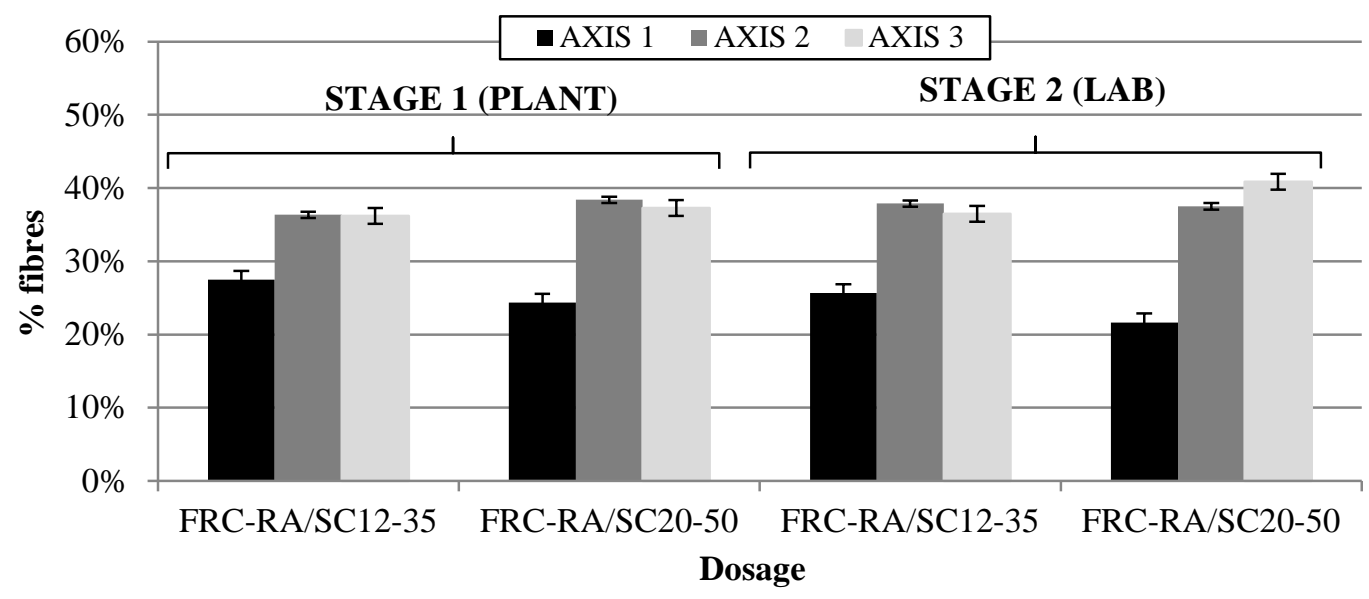




\begin{tabular}{|c|c|c|c|c|c|c|c|c|}
\hline \multirow{3}{*}{ Dosage } & \multicolumn{4}{|c|}{$\mathbf{f}_{\mathbf{c}}(7 \mathrm{~d})$} & \multicolumn{4}{|c|}{$\mathbf{f}_{\mathbf{c}}(28 \mathrm{~d})$} \\
\hline & \multicolumn{2}{|c|}{ Plant } & \multicolumn{2}{|c|}{ Laboratory } & \multicolumn{2}{|c|}{ Plant } & \multicolumn{2}{|c|}{ Laboratory } \\
\hline & $\begin{array}{c}\mathbf{f}_{\mathbf{c m}} \\
\left(\mathrm{N} / \mathrm{mm}^{2}\right)\end{array}$ & $\begin{array}{c}\mathbf{f}_{\mathbf{c k}} \\
\left(\mathrm{N} / \mathrm{mm}^{2}\right)\end{array}$ & $\begin{array}{c}\mathbf{f}_{\mathbf{c m}} \\
\left(\mathrm{N} / \mathrm{mm}^{2}\right)\end{array}$ & \begin{tabular}{|c|}
$\mathbf{f}_{\mathbf{c k}}$ \\
$\left(\mathrm{N} / \mathrm{mm}^{2}\right)$
\end{tabular} & $\begin{array}{c}\mathbf{f}_{\mathbf{c m}} \\
\left(\mathrm{N} / \mathrm{mm}^{2}\right)\end{array}$ & $\begin{array}{c}\mathbf{f}_{\mathbf{c k}} \\
\left(\mathrm{N} / \mathrm{mm}^{2}\right)\end{array}$ & $\begin{array}{c}\mathbf{f}_{\mathbf{c m}} \\
\left(\mathrm{N} / \mathrm{mm}^{2}\right)\end{array}$ & $\begin{array}{c}\mathbf{f}_{\mathbf{c k}} \\
\left(\mathrm{N} / \mathrm{mm}^{2}\right)\end{array}$ \\
\hline NA/SC 12 & $\begin{array}{l}26.21 \\
(2.44) \\
\end{array}$ & 25.16 & $\begin{array}{l}52.31 \\
(4.14)\end{array}$ & 48.76 & $\begin{array}{l}35.03 \\
(6.02)\end{array}$ & 31.57 & $\begin{array}{c}61.48 \\
(1.88)\end{array}$ & 59.58 \\
\hline RA/SC 12 & $\begin{array}{l}24.62 \\
(3.13)\end{array}$ & 23.36 & $\begin{array}{l}29.58 \\
(7.12)\end{array}$ & 26.13 & $\begin{array}{l}33.16 \\
(2.53)\end{array}$ & 31.78 & $\begin{array}{l}37.48 \\
(2.26)\end{array}$ & 36.09 \\
\hline RA/SC 20 & $\begin{array}{l}26.10 \\
(3.49)\end{array}$ & 24.61 & $\begin{array}{l}36.29 \\
(8.03)\end{array}$ & 31.51 & $\begin{array}{l}35.03 \\
(4.48)\end{array}$ & 32.46 & $\begin{array}{l}42.22 \\
(7.22)\end{array}$ & 37.22 \\
\hline RA/SC $20+I$ & $\begin{array}{l}27.08 \\
(2.84)\end{array}$ & 25.82 & $\begin{array}{l}32.31 \\
(6.24)\end{array}$ & 29.00 & $\begin{array}{l}33.06 \\
(2.27)\end{array}$ & 31.83 & $\begin{array}{l}39.57 \\
(0.57)\end{array}$ & 39.20 \\
\hline FRC-RA/SC 12-35 & $\begin{array}{l}30.32 \\
(1.68)\end{array}$ & 29.48 & $\begin{array}{l}29.23 \\
(9.31)\end{array}$ & 24.77 & $\begin{array}{l}37.33 \\
(0.56)\end{array}$ & 36.99 & $\begin{array}{l}38.09 \\
(7.29)\end{array}$ & 33.54 \\
\hline FRC-RA/SC $20-50$ & $\begin{array}{l}34.60 \\
(4.25)\end{array}$ & 32.19 & $\begin{array}{l}38.01 \\
(2.98)\end{array}$ & 36.71 & $\begin{array}{l}44.28 \\
(1.90)\end{array}$ & 42.90 & $\begin{array}{l}38.20 \\
(1.77)\end{array}$ & 37.09 \\
\hline
\end{tabular}

Approximately $70 \%$ to $80 \%$ of the fibres are oriented in the horizontal plane, while $20 \%$ to $25 \%$ remain oriented in the vertical axis. These distributions are independent of the type of fibre employed (M503 or M502). This preferential orientation in the horizontal plane corresponds to the way in which the samples were molded and to the cubic shape. This orientation distribution would be expected in a real element if the self-compactability of the concrete and the pouring system were kept the same. In this sense, it is important to note that in terms of strength, this two-dimensional orientation is favorable because the main tensile stresses are concentrated in the horizontal plane in a large number of structural typologies.

\subsubsection{Mechanical properties}

\section{Compressive strength}

Table 5 shows the average values of compressive strength $\left(\mathbf{f}_{\mathrm{cm}}\right)$ obtained at 7 and $28 \mathrm{~d}$ for the test specimens molded for the respective experimental procedures. In addition, characteristic values of the estimated compressive strength $\left(\mathbf{f}_{\mathrm{ck}}\right)$ using the relationship $\mathbf{f}_{\mathrm{ck}}=$ $\mathbf{f}_{\mathbf{c m}}(1-1.64 \cdot \mathbf{C V})$ are presented.

Table 5. Average compressive strength $f_{c m}\left(\mathrm{CV}\right.$ in \%) and characteristic $f_{c k}$ of test specimens at 7 and $28 d$

The results presented in Table 5 show that the values of $\mathbf{f}_{\mathbf{c k}}$ at $28 \mathrm{~d}$ exceed, for all the dosages, the minimum of $20 \mathrm{~N} / \mathrm{mm}^{2}$ required by the majority of standards for structural unreinforced concrete applications and the value of $25 \mathrm{~N} / \mathrm{mm}^{2}$ for reinforced concrete.

The value of $\mathbf{f}_{\mathbf{c m}}$ for the reference formulation with natural aggregate, NA/SC 12, is significantly greater than that of the formulations with RA. This difference is as high as $6.1 \%(7 \mathrm{~d})$ and $5.7 \%$ $(28 \mathrm{~d})$ for the procedure in the concrete plant, while for the laboratory procedure, the values are $44.1 \%(7 \mathrm{~d})$ and $39.0 \%(28 \mathrm{~d})$. However, the values of $\mathbf{f}_{\mathbf{c m}}$ obtained in the laboratory are, on average, $16.9 \%(7 \mathrm{~d})$ and $8.3 \%$ (28 d) greater than those obtained in the concrete plant.

In accordance with the results of other researchers [71], for concretes fabricated with $\mathbf{w} / \mathbf{c}$ ratios close to 0.40 , the differences in $\mathbf{f}_{\mathbf{c}}$ between a concrete made with natural aggregate and one made with RA can reach values of $25 \%$. [22], for a w/c ratio of 0.50 and cement content of 
$325 \mathrm{~kg} / \mathrm{m}^{3}$, found a $20 \%$ to $25 \%$ reduction in $\mathbf{f}_{\mathbf{c}}$ in those cases in which the coarse fraction was completely replaced with RA from concrete using a process of pre-saturation of the aggregate.

In contrast, in concretes with $\mathbf{w} / \mathbf{c}>0.55$, the $\mathbf{f}_{\mathbf{c}}$ of a recycled-aggregate concrete can be comparable to that of a conventional one, even with substitutions of up to $100 \%$ [72]. [73] attribute this favorable strength behavior of recycled ceramic aggregate to a certain binding capacity due to pozzolanic reactions combined with an internal curing process caused by the reservation of absorbed water during concrete manufacturing.

Finally, for a substitution of $25 \%$ and $50 \%$ of fine natural sand with fine recycled aggregate (with $100 \%$ coarse recycled aggregate in both cases), [66] obtained similar compressive strengths, although it was necessary to compensate for the loss of workability.

\section{Bending strength}

Table 6 shows the results of the bending test carried out on prismatic test specimens with dimensions of $100 \times 100 \times 400 \mathrm{~mm}^{3}$ molded in the concrete plant and the respective values of $\mathbf{f}_{\mathrm{ck}}$ at $28 \mathrm{~d}$. In addition, the values of $\mathbf{f}_{\mathbf{c t m}, \mathrm{fl}}$ are included, as estimated using the expression $\mathbf{f}_{\mathrm{ctm}, \mathrm{fl}}=$ $\mathbf{f}_{\mathrm{ctm}} \cdot(1.6-\mathbf{h} / 1000)$ proposed in EHE-08 for conventional concrete, where $\mathbf{f}_{\mathrm{ctm}}=0.30 \cdot 3 \sqrt{\mathbf{f}_{\mathrm{ck}}}{ }^{2}$ is the average value of the uniaxial tensile strength of the concrete $\left(\mathbf{f}_{\mathrm{ctm}}\right)$ and $\mathbf{h}=100 \mathrm{~mm}$ is the height of the test specimen.

\begin{tabular}{|c|c|c|c|}
\hline Dosage & $\begin{array}{c}\mathbf{f}_{\mathrm{ck}} \\
\left(\mathrm{N} / \mathrm{mm}^{2}\right)\end{array}$ & $\begin{array}{c}\mathbf{f}_{\mathrm{ctm}, \mathrm{fl}, \exp } \\
\left(\mathrm{N} / \mathrm{mm}^{2}\right)\end{array}$ & $\begin{array}{c}\mathbf{f}_{\mathrm{ctm}, \mathrm{fl}, \mathrm{est}} \\
\left(\mathrm{N} / \mathbf{m m}^{2}\right)\end{array}$ \\
\hline RA/SC 12 & 31.78 & 4.71 & $4.51(4.2)$ \\
\hline RA/SC 20 & 32.46 & 4.80 & $4.58(4.6)$ \\
\hline RA/SC $20+I$ & 31.83 & 5.27 & $4.52(14.2)$ \\
\hline FRC-RA/SC 12-35 & 36.99 & 5.24 & $5.00(4.6)$ \\
\hline FRC-RA/SC 20-50 & 42.90 & 5.74 & $5.51(4.0)$ \\
\hline
\end{tabular}

Table 6. Average experimental $f_{c t m, f l \text {,exp }}$ and estimated $f_{c t m, f l, e s t}$ tensile flexural strength (relative error in \%)

The experimental results presented in Table 6 show that the values of $\mathbf{f}_{\mathrm{ctm}, \mathrm{fl}}$ vary between $4.71 \mathrm{~N} / \mathrm{mm}^{2}$ (RA/SC 12) and $5.72 \mathrm{~N} / \mathrm{mm}^{2}$ (FRC-RA/SC 20-50). In contrast to $\mathbf{f}_{\mathrm{ck}}$, the recommendations do not establish a lower limit on the value of $\mathbf{f}_{\mathrm{ct}, \mathrm{fl}}$, given that the reinforcedconcrete structures are designed to permit controlled cracking of the concrete.

Finally, the values of $\mathbf{f}_{\text {ctm,fl,est }}$ estimated using the formulation proposed in EHE-08 agree with those obtained experimentally, with the maximum relative difference being $14.2 \%$ (RA/SC $20+\mathrm{I})$ and, in all cases, from the safe side. Consequently, taking this result into account along with the fact that (1) $\mathbf{f}_{\mathrm{ctm}, \mathrm{f}}$ is a mechanical parameter of lesser importance for the performance in service and failure of reinforced-concrete structures and (2) safety coefficients are applied in the design to cover even higher dispersions, it can be confirmed that it is possible to apply the same formulation to estimate $\mathbf{f}_{\mathrm{ctm}, \mathrm{fl}}$ in recycled-aggregate concrete.

\section{Modulus of elasticity}

Table 7 presents the average values of elastic modulus $\left(\mathbf{E}_{\mathbf{c m}}\right)$ obtained after testing the molded test specimens during the laboratory experimental phase. For each dosage, three test specimens were tested at $28 \mathrm{~d}$ of age and another three at $365 \mathrm{~d}$. The testing ages are 
representative with respect to the time evolution in the magnitude of this basic mechanical property in controlling the deformation response of structures in service.

\begin{tabular}{|c|c|c|c|c|c|}
\hline \multirow{2}{*}{ Dosage } & \multicolumn{3}{|c|}{ RA content $\left.\mathbf{k g} / \mathbf{m}^{3}\right)$} & \multicolumn{2}{c|}{$E_{\mathbf{c m}} \mathbf{( N / \mathbf { m m } ^ { 2 } )}$} \\
\cline { 2 - 6 } & $\mathbf{4 / 1 2 - T - R}$ & $\mathbf{1 2 / 2 0 - T - R}$ & Total & $\mathbf{2 8 ~ d}$ & $\mathbf{3 6 5} \mathbf{~ d}$ \\
\hline NA/SC 12 & 0 & 0 & 0 & 35989 & 42343 \\
\hline RA/SC 12 & 590 & -- & 590 & 22973 & 25404 \\
\hline RA/SC 20 & 180 & 360 & 540 & 25363 & 29182 \\
\hline RA/SC 20+I & 200 & 390 & 590 & 24155 & 27317 \\
\hline
\end{tabular}

Table 7. Values of $E_{c m}$ obtained for the different dosages in the test specimens molded in the laboratory

The content, particle size and nature of the recycled aggregate have a greater impact on the value of $\mathbf{E}_{\mathbf{c m}}$ than on the other mechanical properties analyzed above, mainly because of the configuration of the granular skeleton.

The decrease in $\mathbf{E}_{\mathbf{c m}}$ in the formulations with RA is between $30 \%$ and $35 \%$ at $28 \mathrm{~d}$; the value for the RA/SC 12 dosage at $365 \mathrm{~d}$ approaches the expected value for a conventional concrete with a similar value of $\mathbf{f}_{\text {c. }}$. This characteristic can compromise the use of this material in structures in which deformations are a relevant design factor (e.g., certain bridges and slabs); however, in these cases, the percentage of inclusion of RA could be limited to control the reduction in $\mathbf{E}_{\mathbf{c m}}$. In foundations, earth-retaining walls, or other elements in which the magnitude of deformations is not a determining factor, this reduction is less important.

The results obtained in other studies $[22,27,74-76]$ are consistent with those obtained in this study, and losses between $15 \%$ and $48 \%$ in $\mathbf{E}_{\mathbf{c m}}$ have also been observed in concrete with complete replacement of the coarse fraction by RA with respect to the reference dosages.

The high content of mortar and ceramic material in the RA used and the greater number of aggregate-paste interfaces lead to a greater deformability of RA concrete under load [20]. The mixed RA leads to more deformability than the natural aggregate, and there is a weaker connection between the interfaces of the aggregate and the old paste, presenting a greater number of capillary pores and micro-cracks. Therefore, the total replacement of the coarse fraction of natural aggregates with recycled ones negatively impacts the stiffness [77].

To facilitate assessment of $\mathbf{E}_{\mathbf{c}}$ without having to perform tests, the recommendations include $\mathbf{E}_{\mathbf{c}}-\mathbf{f}_{\mathbf{c}}$ ratios calibrated to conventional concretes based on tests results that have been validated by experience. However, the results obtained with these expressions can be unreliable when these are applied to concrete containing 100\% RA.

To assess the suitability of the existing equations to predict the $\mathbf{E}_{\mathbf{c}}$ for this SFR-SCC-RA, the expressions gathered in the EHE-08 [32], the Eurocode-2[78], the Fédération International du Betón [33], the American Concrete Institute [79], the Brazilian Standard 6118 [80], the Turkish Standard [81] and the Building Regulations of the Federal District of Mexico [82] are analyzed herein. In all cases, the secant modulus of deformation is used, except for [82], which addresses the modulus at the origin $\left(\mathbf{E}_{\mathbf{c i}}\right)$. 
Figure 8 shows the experimental curves of $\mathbf{E}_{\mathbf{c}}-\mathbf{f}_{\mathbf{c}}$ as well as values of $\mathbf{E}_{\mathbf{c}}$ estimated by the equations gathered in Table 8 and the experimental values of $\mathbf{f}_{\mathbf{c}}$ obtained at 28 and $365 \mathrm{~d}$ for each formulation. At the light of the results presented in Figure 8, the values of $\mathbf{E}_{\mathbf{c}}$ experimentally obtained for the reference formulation (NA/SC 12) are within the range of $\mathbf{E}_{\mathbf{c}}$ established by the different empirical equations analyzed, and therefore, the expressions in the standards are valid for estimation of $\mathbf{E}_{\mathbf{c}}$. Specifically, for the range of $\mathbf{f}_{\mathbf{c}}$ values exhibited by the NA/SC 12 dosage, it can be concluded that the EHE-08 formulation would yield the value of $\mathbf{E}_{\mathbf{c}, \min }$ and the NBR 6118 would yield $\mathbf{E}_{\mathbf{c}, \mathbf{m a x}}$. Both expressions proposed in the analyzed standards overestimate the experimental $\mathbf{E}_{\mathbf{c}}$ values for the recycled-aggregate dosages and are thus unsafe.

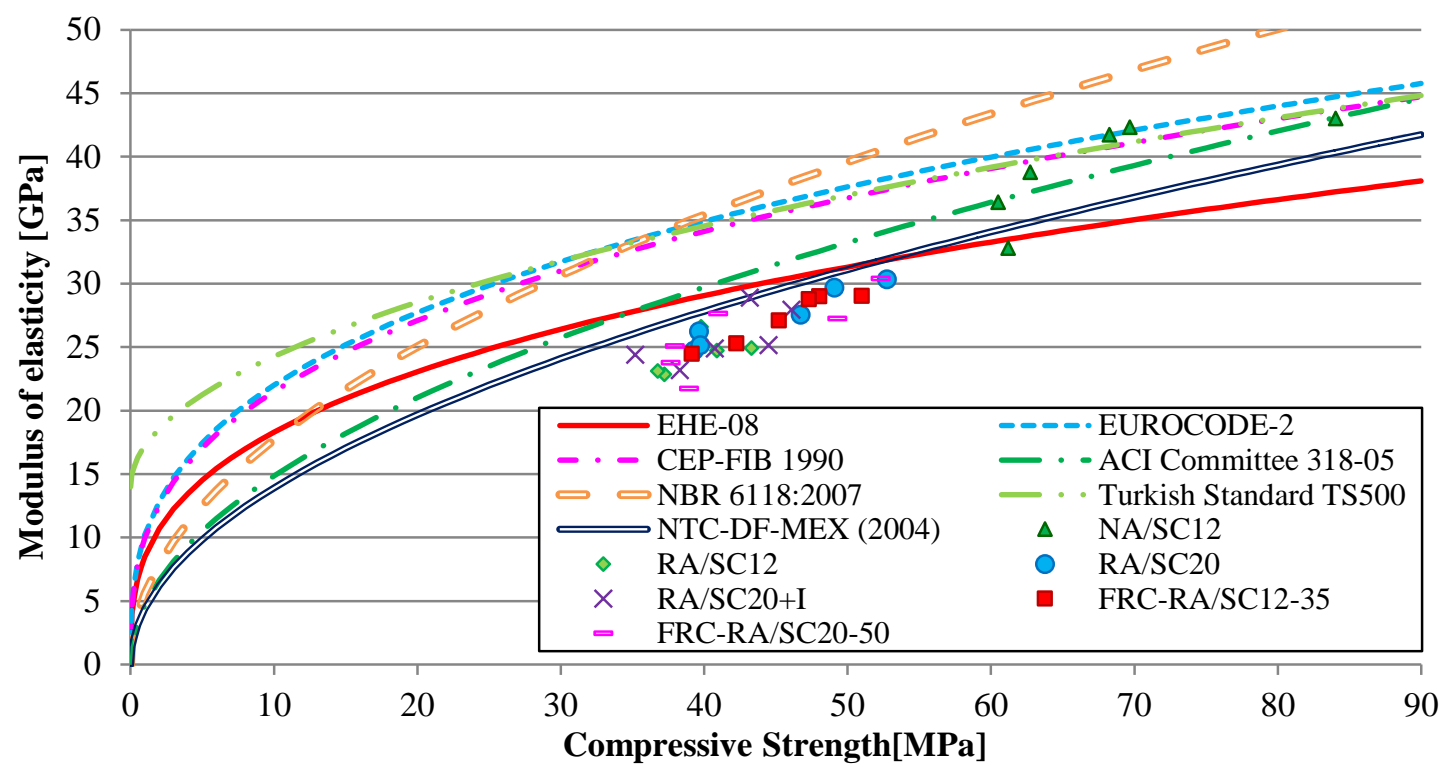

Figure 8. Correlation between $E_{c}$ and $f c$ at 28 and $365 d$ according to the different standards

\begin{tabular}{|c|c|}
\hline Standard & $\mathbf{E}_{\mathbf{c}} \mathbf{( N / \mathbf { m m } ^ { 2 } )}$ \\
\hline EHE-08 (2008) & $E_{c m}=8500 \sqrt[3]{f_{c m}}$ \\
\hline Eurocode-2 (1992) & $E_{c m}=22000 \sqrt[3]{f_{c m} / 10}$ \\
\hline fib (2010) & $E_{c}=21500 \sqrt[3]{f_{c m} / 10}$ \\
\hline ACI 318-05 (2005) & $E_{c}=4700 \sqrt[2]{f_{c}}$ \\
\hline NBR 6118:2014 & $E_{c i}=5600 \sqrt[2]{f_{c k}}$ \\
\hline TS500 (2000) & $E_{c}=3250 \sqrt[2]{f_{c k}}+14,000$ \\
\hline NTC-DF-MEX (2004) & $E_{c}=4400 \sqrt[2]{f^{\prime}}$ \\
\hline
\end{tabular}

Table 8. Empirical equations proposed in different standards for estimating $E_{c}$ based on $f_{c}$

Based on the results, corrections to the existing formulations are proposed with the goal of adapting these to recycled-aggregate concrete. In this sense, various authors [83-91] have already proposed expressions. However, none of these studies addresses the case of concretes with the coarse fraction composed of $100 \%$ mixed RA. 
507

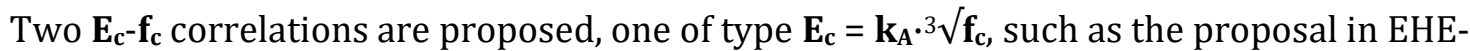

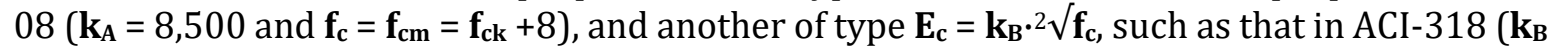
$=4,700$ and $\mathbf{f}_{\mathbf{c}}=\mathbf{f}_{\mathbf{c m}}$ ) for conventional concretes. The constants $\mathbf{k}_{\mathbf{A}}$ and $\mathbf{k}_{\mathbf{B}}$ are calibration factors that have been obtained numerically (Table 9) by the method of least squares.

\begin{tabular}{|c|c|c|c|c|c|}
\hline Dosage & $\begin{array}{c}\text { RA content } \\
\left(\mathbf{k g} / \mathbf{m}^{3} \mathbf{)}\right.\end{array}$ & $\begin{array}{c}\mathbf{C}_{\mathbf{f}} \\
\left(\mathbf{k g} / \mathbf{m}^{\mathbf{3}} \mathbf{)}\right.\end{array}$ & $\mathbf{N} \mathbf{0}$ & $\mathbf{k}_{\mathbf{A}}$ & $\mathbf{k}_{\mathbf{B}}$ \\
\hline NA/SC 12 & 0 & 0 & 6 & 9634 & 4770 \\
\hline RA/SC 12 & 590 & 0 & 6 & 7173 & 3884 \\
\hline RA/SC 20 & 540 & 0 & 6 & 7716 & 4097 \\
\hline RA/SC 20+I & 590 & 0 & 6 & 7455 & 4008 \\
\hline FRC-RA/SC12-35 & 520 & 20 & 6 & 7647 & 4046 \\
\hline FRC-RA/SC 20-50 & 520 & 20 & 6 & 7452 & 3982 \\
\hline
\end{tabular}

Table 9. $k_{A}$ and $k_{B}$ parameters for the proposed empirical ratios $E_{c}-f_{c}$

The values of $\mathbf{k}_{\mathbf{A}}$ and $\mathbf{k}_{\mathbf{B}}$ calculated for the concretes with $\mathrm{AR}$, as might be expected, are lower than the values of 8,500 proposed in EHE-08 and 4,700 proposed in ACI 318-05, respectively. The greatest reduction corresponds in both cases to the RA/SC 12 formulation (15.6\% for $\mathbf{k}_{\mathbf{A}}$ and $17.3 \%$ for $\mathbf{k}_{\mathbf{B}}$ ) containing $590 \mathrm{~kg}$ of RA 4/12-T-R, while the smallest reduction is found in the RA/SC 20 formulation $\left(9.2 \%\right.$ for $\mathbf{k}_{\mathbf{A}}$ and $12.9 \%$ for $\left.\mathbf{k}_{\mathrm{B}}\right)$ containing $180 \mathrm{~kg}$ of RA 4/12-T-R and $360 \mathrm{~kg}$ of RA 12/20-T-R.

The reference formulation NA/SC 12 specifies $\mathbf{k}$ values $13.3 \%$ and 1.5\% higher than those established in EHE-08 and ACI-318, respectively. In addition, the inclusion of $20 \mathrm{~kg} / \mathrm{m}^{3}$ in the formulation does not substantially alter the values of $\mathbf{k}$ (or, consequently, the values of $\mathbf{E}_{\mathbf{c}}$ ) with respect to the other formulations with RA. Finally, the expressions Equations 1 and 2 are those proposed and adapted to estimate the average value of the modulus $\mathbf{E}_{\mathbf{c}}$ as a function of $\mathbf{f}_{\mathbf{c}}$ and of the RA content $\left(\mathbf{C}_{\mathbf{A R}}\right.$, in $\left.\mathrm{kg} / \mathrm{m}^{3}\right)$.

$$
\begin{aligned}
& E_{c m}=8,500\left(1-0.000216 C_{A R}\right) \sqrt[3]{f_{c m}} \\
& E_{c m}=4,700\left(1-0.000268 C_{A R}\right) \sqrt[2]{f_{c m}}
\end{aligned}
$$

508

509

510

511

512

513

514

515

\section{Cracking and post-cracking behavior}

The tensile behavior, including the post-cracking response, has been estimated indirectly in the FRC-RA/SC 12-35 and FRC-RA/SC 20-50 formulations manufactured in the laboratory via the BCN test with cylindrical specimens by controlling the circumferential deformation during the test [55]. Jack force curves (F) - total crack opening displacement (TCOD) and fracture energy released during the test $\left(\mathbf{G}_{\mathbf{f}}\right)$ are presented in Figure 9 . The average curves obtained from a total number of three tests for each formulation are presented. 


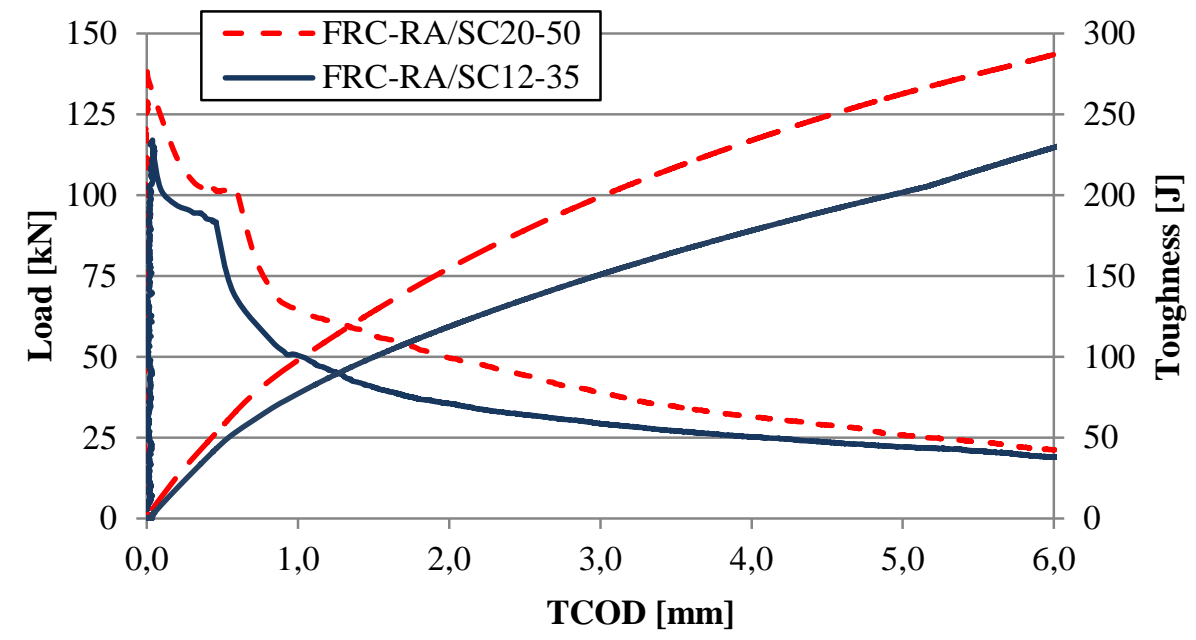

Figure 9. Curves of vertical load-total crack width obtained with the BCN test

The curves in Figure 9 confirm the following: (1) upon reaching the cracking load $\mathbf{F}_{\mathbf{c r}}(121$ $\mathrm{kN}$ for FRC-RA/SC 12-35 and $141 \mathrm{kN}$ for FRC-RA/SC 20-50) a softening behavior occurs, but with an associated ductile behavior (no brittle fracture), due to the strong contribution of the fibres, and (2) the FRC-RA/SC 20-50 dosage presents a greater post-cracking load than FRCRA/SC 20-35 due to the greater slenderness of the M502 fibre $\left(\lambda_{\mathbf{f}}=50\right)$ and therefore greater spatial efficiency for reduced values of $\mathbf{C}_{\mathbf{f}}\left(20 \mathrm{~kg} / \mathrm{m}^{3}\right)$ with respect to the M503 fibre $\left(\boldsymbol{\lambda}_{\mathbf{f}}=35\right)$. However, this behavior cannot be generalized because, for greater $\mathbf{C}_{\mathbf{f}}$ values, the trends can be inverted due to the greater number of fibres per kg of M503 compared to M502 (see Table 2).

Furthermore, using the proposed model by [92] and the BCN test results of cylindrical and cubic specimens, $\mathrm{f}_{\mathrm{ctm}, \mathrm{fl}}$ has been estimated as well as the average values of residual flexural postcracking strength $\left(f_{R m}\right)$ for different values of crack width $\left(f_{R m 1}, f_{R m 2}, f_{R m 3}\right.$ and $f_{R m 4}$ associated with crack widths of $0.50,1.50,2.50$ and $3.50 \mathrm{~mm}$, respectively); see Table 10.

\begin{tabular}{|c|c|c|c|c|c|}
\hline Dosage & $\begin{array}{c}\mathbf{f}_{\mathrm{ctm}, \mathbf{f l}} \\
\left(\mathbf{N} / \mathbf{m m}^{\mathbf{2}} \mathbf{)}\right.\end{array}$ & $\begin{array}{c}\mathbf{f}_{\mathrm{Rm} \mathbf{1}} \\
\left(\mathbf{N} / \mathbf{m m}^{\mathbf{2}} \mathbf{)}\right.\end{array}$ & $\begin{array}{c}\mathbf{f}_{\mathrm{Rm} \mathbf{2}} \\
\left(\mathbf{N} / \mathbf{m m}^{\mathbf{2}} \mathbf{)}\right.\end{array}$ & $\begin{array}{c}\mathbf{f}_{\mathrm{Rm} \mathbf{3}} \\
\left(\mathbf{N} / \mathbf{m m}^{\mathbf{2}} \mathbf{)}\right.\end{array}$ & $\begin{array}{c}\mathbf{f}_{\mathrm{Rm} \mathbf{4}} \\
\left(\mathbf{N} / \mathbf{m m}^{\mathbf{2}} \mathbf{)}\right.\end{array}$ \\
\hline FRC-RA/SC 12-35 & 4.416 & 0.895 & 0.808 & 0.636 & 0.480 \\
\hline FRC-RA/SC 20-50 & 5.289 & 1.249 & 1.115 & 0.793 & 0.535 \\
\hline
\end{tabular}

Table 10. Values of $f_{c t m, f l}$ and $f_{R m i}$ for the HRF dosages

From the results gathered in table 10 it can be derived that $\mathbf{f}_{\mathbf{R} 1} / \mathbf{f}_{\mathbf{c t m}, \mathbf{f l}}$ ratio is 0.20 (FRCRA/SC 12-35) and 0.23 (FRC-RA/SC 20-50), which is lower than the minimum value of 0.40 proposed by fib MC-2010 [33] to substitute part of the passive reinforcement with $\mathbf{C}_{\mathbf{f}}$ of 20 $\mathrm{kg} / \mathrm{m}^{3}$ used in both concrete dosages. However, SFR-SCC-RA itself could be used as a structural concrete with improved ductility over unreinforced concrete. In the case of adding conventional reinforcement, cracked phase (crack width control) would be benefit from the toughness of this FRC material; simultaneously, by increasing the value of $\mathbf{C}_{\mathbf{f}}$ a ratio of $\mathbf{f}_{\mathbf{R} 1} / \mathbf{f}_{\mathbf{c t m}, \mathrm{fl}}>0.40$ could be reached and therefore replace some or all of the passive reinforcement with the additions of fibres, with advantages derived in terms of sustainability (economic, social and environmental).

\section{CONCLUSIONS}


The aim of this paper was to present a new cement base material whose coarse fraction of aggregate is $100 \%$ recycled and of mixed nature, with properties of self-compactability and with the inclusion of structural fibres to improve its ductility and toughness, classified as SFRSCC-RA. In the current experimental phase, its design has been oriented to applications with limited structural responsibility, such as foundation and earth-retaining elements subjected to reduced bending stresses.

Extensive experimental campaigns have been conducted to verify suitability and adaptability to existing manufacturing and implementation systems and to characterize the most relevant physical and mechanical properties. The resulting findings are as follows:

- The following two types of treatments of recycled aggregates were analyzed: presaturation with water and the use of a water-repellent additive. Pre-saturation was found to be more effective. The additive was not sufficiently effective to completely envelop the aggregates and prevent part of the water used for cement hydration from being absorbed.

- If the aggregates are properly pre-saturated, these do not alter the consistency of fresh concrete; a more fluid consistency can even be achieved if recycled aggregates are introduced in the saturated state with a dry surface.

- Steel fibres reduce the flowability of fresh concrete, and this effect is accentuated for fibres of high slenderness. To ensure self-compactability of the concrete for fibres of high slenderness $\left(\lambda_{\mathrm{f}}=50\right)$, the content of fine aggregate and of superplasticizer can be increased in the formulation.

- A reduction of approximately $6.5 \%$ in the density was detected compared to the standard formulation (no recycled aggregate). This reduction is expected and depends on the characteristics of the aggregate and the composition of the granular skeleton.

- The compressive strength was reduced by $30 \%$ to $40 \%$ in comparison with the reference formulation. However, values ranging between 35 and $40 \mathrm{~N} / \mathrm{mm}^{2}$ at $28 \mathrm{~d}$ make this material suitable for structural elements subjected to moderate loads.

- The deformation modulus also exhibits similar reductions on the same order as the compressive strength; however, the experimental values obtained $(23,000$ to 30,000 $\mathrm{N} / \mathrm{mm}^{2}$ ) are compatible with applications in which the limitations of deformability are a secondary consideration at the design level. Two equations were proposed to estimate the deformation modulus depending on the compressive strength to account for the amount of recycled aggregate present in the formulation.

- Magnetic tests carried out on molded specimens indicated that at least $70 \%$ of the fibres were oriented in the horizontal plane. Principle tensile stresses were generally produced in this plane during service, enabling the fibres to act effectively.

- The amount of metal fibres employed in HRF formulations $\left(20 \mathrm{~kg} / \mathrm{m}^{3}\right)$ was shown to be effective in ensuring ductile post-cracking behavior; however, in applications in which one intends to replace part or all of the passive reinforcement in the form of bars, it is necessary to increase the amount of fibres. 
611

612

613

614

615

616

617

618

619

620

621

622

623

624

625

626

627

628

629

630

631

632

633

634

635

636

At present, a structural application of this material in the screens of an underground parking garage located in Barcelona has been carried out with satisfactory results at the technical level; furthermore, durability tests are being developed to verify that this material is compatible with the requirements stipulated by the regulations. In this regard, the first durability test (chloride corrosion and sulfate attack) was also satisfactory; however, a larger test population is needed to confirm its suitability.

\section{ACKNOWLEDGMENTS}

The authors wish to thank the Government of Catalonia, as well as ESCOFET 1886, S.A., for the scholarship granted within the Industrial Doctorates Project. Special thanks to the technicians of the Structure Technology Laboratory Luis Agulló of Barcelona Tech.

\section{REFERENCES}

[1] Aguado A, Barra M, Gomez-Soberon JM, Gonzales B. Potencialidades del Hormigón Estructural y su Tecnología en el Marco de la Sostenibilidad de la Construcción. Hormig Acero 2003;228:20712.

[2] Bhattacharya S, Ghosh SP, Srinivasan AV. GHG, other Gases and Pollutant Emission Trends and Projections for the Cement Industry in India, Durban, South Africa: The Cement and Concrete Institute of South Africa, Editors: Grieve, G. and Owens, G.; 2003, p. 1292-312.

[3] De Rougemont F. Sustainable Development in the Cement Industry: the South African Record, Durban, South Africa: The Cement and Concrete Institute of South Africa, Editors: Grieve, G. and Owens, G.; 2003, p. 9-17.

[4] Cândido L, Kindlein W, Demori R, Carli L, Mauler R, Oliveira R. The recycling cycle of materials as a design project tool. J Clean Prod 2011;19:1438-45. doi:10.1016/j.jclepro.2011.04.017.

[5] Adazabra AN, Viruthagiri G, Ravisankar R. Cleaner production in the Shea industry via the recovery of Spent Shea Waste for reuse in the construction sector. J Clean Prod 2016;122:335-44. doi:10.1016/j.jclepro.2016.02.045.

[6] Blessen Skariah T, Ramesh Chandra G, Vinu John P. Recycling of waste tire rubber as aggregate in concrete: durability-related performance. J Clean Prod 2016;112:504-13. doi:10.1016/j.jclepro.2015.08.046.

[7] Bogas JA, de Brito J, Ramos D. Freezeethaw resistance of concrete produced with fine recycled concrete aggregates. J Clean Prod 2016;115:294-306. doi:10.1016/j.jclepro.2015.12.065.

[8] Sua-Iam G, Makul N. Utilization of coal- and biomass-fired ash in the production of selfconsolidating concrete: a literatura review. J Clean Prod 2015;100:59-76. doi:10.1016/j.jclepro.2015.03.038.

[9] Etxeberria M, Ainchil J, Pérez Ma E, González A. Use of recycled fine aggergates for Control Low Strength Materials (CLSMs) production. Constr Build Mater 2013; 44:142-148. doi:10.1016/j.conbuildmat.2013.02.059

[10] Gonzalez-Corominas A, Etxeberria M. Properties of high performance concrete made with recycled fine ceramic and coarse mixed aggregates. Constr Build Mater 2014; 68:618-626. doi:10.1016/j.conbuildmat.2014.07.016 
666

667

668

669

670

671

672

673

674

675

676

677

678

679

[11] Gonzalez-Corominas A, Etxeberria M. Effects of using recycled concrete aggregates on the shrinkage of high performance concrete. Constr Build Mater 2016; 115:32-41. doi:10.1016/j.conbuildmat.2016.04.031

[12] EUROPEAN AGGREGATES ASSOCIATION. EUROPEAN AGGREGATES ASSOCIATION A Sustainable Industry for a Sustainable Europe Annual Review 2015-2016. Rue D' Arlon 21 - 1050 Brussels, Belgium: EUROPEAN AGGREGATES ASSOCIATION; 2012.

[13] Behera M, Bhattacharyya SK, Minocha AK, Deoliya R, Maiti S. Recycled aggregate from C\&D waste \& its use in concrete - A breakthrough towards sustainability in construction sector: A review. Constr Build Mater 2014;68:501-16. doi:10.1016/j.conbuildmat.2014.07.003.

[14] Agrela F, Barbudo A, Ramírez A, Ayuso J, Carvajal MD, Jiménez JR. Construction of road sections using mixed recycled aggregates treated with cement in Malaga, Spain. Resour Conserv Recycl 2012;58:98-106. doi:10.1016/j.resconrec.2011.11.003.

[15] Herrador R, Pérez P, Garach L, Ordóñez J. Use of Recycled Construction and Demolition Waste Aggregate for Road Course Surfacing. J Transp Eng 2012;138:182-90. doi:10.1061/(ASCE)TE.1943-5436.0000320.

[16] Jíménez JR, Agrela F, Ayuso J, López M. Estudio comparativo de los áridos reciclados de hormigón y mixtos como material para sub-bases de carreteras. Mater Constr 2011;61:289-302. doi:10.3989/mc.2010.54009.

[17] Park T. Application of construction and building debris as base and subbase materials in rigid pavement. J Transp Eng 2003;129:558-63. doi:10.1061/(ASCE)0733-947X(2003)129:5(558).

[18] Bravo M, de Brito J, Pontes J, Evangelista L. Durability performance of concrete with recycled aggregates from construction and demolition waste plants. Constr Build Mater 2015;77:357-69. doi:10.1016/j.conbuildmat.2014.12.103.

[19] Sánchez de Juan M, Alaejos Gutiérrez P. Study on the influence of attached mortar content on the properties of recycled concrete aggregate. Constr Build Mater 2009;23:872-7. doi:10.1016/j.conbuildmat.2008.04.012.

[20] Poon CS, Shui ZH, Lam L. Effect of microstructure of ITZ on compressive strength of concrete prepared with recycled aggregates. Constr Build Mater 2004;18:461-8. doi:10.1016/j.conbuildmat.2004.03.005.

[21] Barra M. Estudio de la durabilidad del hormigón de árido reciclado en su aplicación como hormigón armado. PhD Thesis. Universitat Politecnica de Catalunya, 1996.

[22] Etxeberria M, Marí AR, Vázquez E. Recycled aggregate concrete as structural material. Mater Struct 2007;40:529-41. doi:10.1617/s11527-006-9161-5.

[23] Marinković S, Radonjanin V, Malešev M, Ignjatović I. Comparative environmental assessment of natural and recycled aggregate concrete. Waste Manag 2010;30:2255-64. doi:10.1016/j.wasman.2010.04.012.

[24] Marie I, Quiasrawi H. Closed-loop recycling of recycled concrete aggregates. J Clean Prod 2012;37:243-8. doi:10.1016/j.jclepro.2012.07.020.

[25] López-Gayarre F, Serna P, Domingo-Cabo A, Serrano-López MA, López-Colina C. Influence of recycled aggregate quality and proportioning criteria on recycled concrete properties. Waste Manag 2009;29:3022-8. doi:10.1016/j.wasman.2009.07.010.

[26] Rahal K. Mechanical properties of concrete with recycled coarse aggregate. Build Environ 2007;42:407-15. doi:10.1016/j.buildenv.2005.07.033. 
706

707

708

709

710

711

712

713

714

715

716

717

718

719

720

721

[27] Xiao J, Li J, Zhang C. Mechanical properties of recycled aggregate concrete under uniaxial loading. Cem Concr Res 2005;35:1187-94. doi:10.1016/j.cemconres.2004.09.020.

[28] García J, Rodríguez D, Juan A, Morán JM, Guerra MI. Pre-saturación de los áridos reciclados procedentes de residuos de construcción y demolición para la fabricación de hormigones ecoeficientes. Mem. VI Congr. Int. Estruct. ACHE, Madrid: ACHE (Asociación Científico-Técnica del Hormigón Estructural); 2014.

[29] Tegguer AD. Determining the water absorption of recycled aggregates utilizing hydrostatic weighing approac. Constr Build Mater 2012;27:112-6. doi:10.1016/j.conbuildmat.2011.08.018.

[30] Klein NS. El rol físico del agua en mezclas de cemento Portland. PhD Thesis. Universitat Politècnica de Catalunya, 2012.

[31] Silva RV, De Brito J, Dhir RK. Properties and composition of recycled aggregates from construction and demolition waste suitable for concrete production. Constr Build Mater 2014;65:201-17. doi:10.1016/j.conbuildmat.2014.04.117.

[32] Comisión Permanente del Hormigón (CPH). Code on Structural Concrete (EHE 2008). Madrid: Ministerio de Fomento, Gobierno de España; 2008.

[33] The International Federation for Structural Concrete (fib). The fib Model Code for Concrete Structures 2010. KGaA, Weinheim, German: Wiley-VCH Verlag GmbH \& Co.; 2013.

[34] Di Prisco M, Plizzari G, Vandewalle L. Fibre reinforced concrete: New design perspectives. Mater Struct 2009;42:1261-81. doi:10.1617/s11527-009-9529-4.

[35] Walraven JC. High performance fibre reinforced concrete: progress in knowledge and design codes. Mater Struct 2009;42:1247. doi:10.1617/s11527-009-9538-3.

[36] de la Fuente A, Pujadas P, Blanco A, Aguado A. Experiences in Barcelona with the use of fibres in segmental linings. Tunn Undergr Space Technol 2012;27:60-71. doi:10.1016/j.tust.2011.07.001.

[37] Liao L, de la Fuente A, Cavalaro S, Aguado A. Design procedure and experimental study of fibre reinforced concrete segmental rings for vertical shafts. Mater Des 2016;92:590-601. doi:10.1016/j.matdes.2015.12.061.

[38] Liao L, de la Fuente A, Cavalaro S, Aguado A. Design of FRC tunnel segments considering the ductility requirements of the MC 2010. Tunn Undergr Space Technol 2015;47:200-10. doi:10.1016/j.tust.2015.01.006.

[39] de la Fuente A, Escariz RC, De Figueiredo AD, Aguado A. Design of macro-synthetic fibre reinforced concrete. Constr Build Mater 2013;43:523-32. doi:10.1016/j.conbuildmat.2013.02.036.

[40] de la Fuente A, Escariz RC, De Figueiredo AD, Molins C, Aguado A. A new design method for steel fibre reinforced concrete pipes. Constr Build Mater 2012;30:547-55. doi:10.1016/j.conbuildmat.2011.12.015.

[41] de la Fuente A, Blanco A, Armengou J, Aguado A. Sustainability based-approach to determine the concrete type and reinforcement configuration of TBM tunnel linings. Case study: extension line to Barcelona Airport T1. Tunn Undergr Space Technol 2017;61:179-88. doi:10.1016/j.tust.2016.10.008.

[42] Casanovas M del M, Armengou J, Ramos G. Occupational risk index for assessment of risk in construction work by activity. J Constr Eng Manag 2014;140. doi:10.1061/(ASCE)CO.19437862.0000785 . 
[43] EN 933-1. Tests for geometrical properties of aggregates - Part 1: Determination of particle size distribution - Sieving method. CEN - European Committee for Standarization; 2012.

[44] EN 933-2. Test for geometrical properties of aggregates. Part 2: determination of particle size distribution. Test sieves, nominal size of apertures. CEN - European Committee for Standarization; 1995.

[45] EN 933-11. Tests for geometrical properties of aggregates - Part 11: Classification test for the constituents of coarse recycled agggregate. CEN - European Committee for Standarization; 2009.

[46] EN 1097-3. Tests for mechanical and physical properties of aggregates - Part 3: Determination of loose bulk density and voids. CEN - European Committee for Standarization; 1998.

[47] EN 1097-6. Tests for mechanical and physical properties of aggregates - Part 6: Determination of particle density and water absorption. CEN - European Committee for Standarization; 2013.

[48] Chiaia B, Fantilli AP, Vallini P. Minimum reinforcement and fibre contribution in tunnel linings: the Italian experience. Proc. Fourth Int. Struct. Eng. Constr. Conf., Melbourne: Taylor \& Francis Group; 2007, p. 365-70. doi:porto.polito.it/id/eprint/1660903.

[49] Fantilli AP, Chiaia B, Gorino A. Unified Approach for Minimum Reinforcement of Concrete Beams. ACI Struct J 2016;113:1107-16. doi:10.14359/51688927.

[50] EN 12350-8. Testing fresh concrete - Part 8: Self-compacting concrete - Slump-flow test. CEN European Committee for Standarization; 2010.

[51] IHOBE SP de GA. Usos de áridos reciclados mixtos procedentes de Residuos de Construcción y Demolición. Investigación prenormativa. Bilbao, Spain: Departamento de Medio Ambiente, Planificación Territorial, Agricultura y Pesca. Gobierno Vasco.; 2011.

[52] Tam VWY, Gao XF, Tam CM. Microstructural analysis of recycled aggregate concrete produced from two-stage mixing approach. Cem Concr Res 2005;35:1195-203. doi:10.1016/j.cemconres.2004.10.025.

[53] Torrents JM, Blanco A, Pujadas P, Aguado A, Juan-García P, Sánchez-Moragues MA. Inductive method for assessing the amount and orientation of steel fibres in concrete. Mater Struct 2012;45:1577-92. doi:10.1617/s11527-012-9858-6.

[54] Molins C, Aguado A, Saludes S. Double Punch Test to control the energy dissipation in tension of FRC (Barcelona test). Mater Struct 2008;42:415-25. doi:10.1617/s11527-008-9391-9.

[55] UNE 83515. Fibre reinforced concrete. Determination of cracking strength, ductility and residual tensile strength. Barcelona test. AENOR - Spanish Association for Standardisation and Certification; 2010.

[56] Pujadas P, Blanco A, Cavalaro SHP, Aguado A, Grünewald S, Blom K, Walraven J.C. Plastic fibres as the only reinforcement for flat suspended slabs: Parametric study and design considerations. Constr Build Mater 2014;70:88-96. doi:10.1016/j.conbuildmat.2014.07.091.

[57] Pujadas P, Blanco A, Cavalaro S, de la Fuente A, Aguado A. New analytical model to generalize the Barcelona test using axial displacement. J Civ Eng Manag 2013;19:259-71. doi:10.3846/13923730.2012.756425.

[58] EN 1936. Natural stone test methods. Determination of real density and apparent density, and of total and open porosity. CEN - European Committee for Standarization; 2006.

[59] EN 12390-3. Testing hardened concrete - Part 3: Compressive strength of test specimens. CEN European Committee for Standarization; 2009. 
[60] EN 12390-5. Testing hardened concrete - Part 5: Flexural strength of test specimens. CEN European Committee for Standarization; 2009.

[61] EN 12390-13. Testing hardened concrete - Part 13: Determination of secant modulus of elasticity in compression. CEN - European Committee for Standarization; 2013.

[62] Grünewald S, Walraven JC. Parameter-study on the influence of steel fibres and coarse aggregate content on the fresh properties of self-compacting concrete. Cem Concr Res 2001;31:1793-8. doi:10.1016/S0008-8846(01)00555-5.

[63] El-Dieb AS, Reda Taha MM. Flow characteristics and acceptance criteria of fibre-reinforced selfcompacted concrete (FR-SCC). Constr Build Mater 2012;27:585-96. doi:10.1016/j.conbuildmat.2011.07.004.

[64] Okamura H, Ouchi M. Self-Compacting Concrete. J Adv Concr Technol 2003;1:5-15. doi:doi.org/10.3151/jact.1.5.

[65] Skarendahl Å, Petersson Ö. Self-Compacting Concrete - State-of-the-Art Report of RILEM TC 174SCC. RILEM; 2000.

[66] Kou SC, Poon SC. Properties of self-compacting concrete prepared with coarse and fine recycled concrete aggregates. Cem Concr Compos 2009;31:622-7. doi:10.1016/j.cemconcomp.2009.06.005.

[67] Martínez-Lage I, Martínez-Abella F, Vázquez-Herrero C, Pérez-Ordóñez JL. Properties of plain concrete made with mixed recycled coarse aggregate. Constr Build Mater 2012;37:171-6. doi:10.1016/j.conbuildmat.2012.07.045.

[68] Gómez-Soberón JMV. Porosity of recycled concrete with substitution of recycled concrete aggregate: An experimental study. Cem Concr Res 2002;32:1301-11. doi:10.1016/S00088846(02)00795-0.

[69] González-Fonteboa B, Martínez-Abella F, Eiras-López J, Seara-Paz S. Effect of recycled coarse aggregate on damage of recycled concrete. Mater Struct 2011;44:1759-71. doi:10.1617/s11527011-9736-7.

[70] Grdic Z], Toplicic-Curcic GA, Despotovic IM, Ristic NS. Properties of self-compacting concrete prepared with coarse recycled concrete aggregate. Constr Build Mater 2010;24:1129-33. doi:10.1016/j.conbuildmat.2009.12.029.

[71] Sheen Y-N, Wang H-Y, Juang Y-P, Le D-H. Assessment on the engineering properties of readymixed concrete using recycled aggregates. Constr Build Mater 2013;45:298-305. doi:10.1016/j.conbuildmat.2013.03.072.

[72] Rao A. Experimental Investigation on Use of Recycled Aggregates in Mortar and Concrete. Thesis. Departament of Civil Engineering, Indian Institute of Technology Kampur, 2005.

[73] Gonzalez-Corominas A, Etxeberria M. Properties of high performance concrete made with recycled fine ceramic and coarse mixed aggregates. Constr Build Mater 2014;68:618-26. doi:10.1016/j.conbuildmat.2014.07.016.

[74] Kou SC, Poon CS. Mechanical properties of 5-year old concrete prepared with recycled aggregates obtained from three different sources. Mag Concr Res 2008;60:57-64. doi:10.1680/macr.2007.00052.

[75] Li JB. Study on mechanical behavior of recycled aggregate concrete. Master Thesis. Tongji University, 2004. 
[76] Rao MC, Bhattacharyya SK, Barai SV. Influence of field recycled coarse aggregate on properties of concrete. Mater Struct 2011;44:205-20. doi:10.1617/s11527-010-9620-x.

[77] Mena Sebastia F. Características estructurales del hormigón con árido reciclado mixto reforzado con fibras. Ph.D. Thesis. Universitat Politécnica de Catalunya, 2015.

[78] EN 1992-1-1. Eurocode 2: Design of Concrete Structures - Part 1: General rules and rules for buildings. CEN - European Committee for Standarization; 2004.

[79] ACI Committee 318. Building Code Requirements for Structural Concrete and Commentary. ACI American Concrete Institute; 2014.

[80] ABNT NBR 6118. Design of structural concrete - Procedure. ABNT - Associação Brasileira de Normas Técnicas; 2014.

[81] TS 500/T1. Requirements for design and construction of reinforced concrete structures. Turkish Standards Institution; 2000.

[82] NTC 2014. Normas técnicas complementarias para diseño y construcción de estructuras de concreto. Mexico, D.F.: Instituto para la Seguridad de las Construcciones en el D.F.; 2004.

[83] Corninaldesi V. Mechanical and elastic behavior of concretes made of recycled-concrete coarse aggregates. Constr Build Mater 2010;24:1616-20. doi:10.1016/j.conbuildmat.2010.02.031.

[84] Dhir RK, Limbachiya MC, Leelawat T. Suitability of recycled aggregate for use in BS 5328 designates mixes. Proc Inst Civ Eng - Struct Build 1999;134:257-74. doi:10.1680/istbu.1999.31568.

[85] Dillmann R. Concrete with recycled concrete aggregate. Sustain. Constr. Use Recycl. Concr. Aggreg., Dundee, Scotland: Thomas Telford; 2015. doi:10.1680/scuorca.27268.0021.

[86] Evangelista L, De Brito J. Mechanical behaviour of concrete made with fine recycled concrete aggregates. Cem Concr Compos 2007;29:397-401. doi:10.1016/j.cemconcomp.2006.12.004.

[87] Kou S-C, Poon C-S. Long-term mechanical and durability properties of recycled aggregate concrete prepared with the incorporation of fly ash. Cem Concr Compos 2013;37:12-9. doi:10.1016/j.cemconcomp.2012.12.011.

[88] Mellmann G, Meinhold U, Maultzsch M. Processed concrete rubble for the reuse as aggregate. Proc. Int. Semin. Exploit. Wastes Concr., Dundee, Scotland: Ravindra K. Dhir and Trevor G. Jappy; 2015, p. 171-8. doi:10.1680/ewic.28210.0016.

[89] Ravindrarajah RS, Tam CT. Properties of concrete made with crushed concrete as coarse aggregate. Mag Concr Res 1985;37:29-38. doi:10.1680/macr.1985.37.130.29.

[90] Tangchirapat W, Rattanashotinunt C, Buranasing R, Jaturapitakkul C. Influence of fly ash on slump loss and strength of concrete fully incorporating recycled concrete aggregates. J Mater Civ Eng 2013;25:243-51. doi:10.1061/(ASCE)MT.1943-5533.0000585.

[91] Zilch K, Roos F. An equation to estimate the modulus of elasticity of concrete with recycled aggregates. Civ Eng 2001;76:187-91.

[92] Blanco A, Pujadas P, de la Fuente A, Cavalaro S, Aguado A. Application of constitutive models in European codes to RC-FRC. Constr Build Mater 2013;40:246-59. doi:10.1016/j.conbuildmat.2012.09.096. 